\title{
Stefnuyfirfærsla: Áhrif Efnahags- og framfarastofnunarinnar (OECD) á stefnumótun á Íslandi
}

\begin{abstract}
Pétur Berg Matthíasson, stjórnmála- og stjórnsýslufræđingur, forsætisráduneytinu
\end{abstract}

\begin{abstract}
Útdráttur
Alpjóðastofnanir á borð við Efnahags- og framfarastofnunina (OECD), Sameinuðu pjóðirnar (Sp), Alpjóðagjaldeyrissjóðinn (AGS) og Alpjóðabankann eru pekktar fyrir að standa að baki útbreiðslu hugmynda, gilda og stefnumála um heim allan. Á 10. áratugnum jókst áhugi fræðimanna á viðfangsefni sem kallað er hér stefnuyfirfærsla (e. policy transfer). Tilraunir fræðimanna fólust m.a. í pví að setja ramma utan um nálgunina og skýra af hverju yfirfærsla á sér stað, við hvaða aðstæður, á hvaða stigi o.s.frv. Fátt hefur verið meira rannsakað innan stjórnsýslufræðanna undanfarna áratugi erlendis en viðfangsefnið hefur lítið borið á góma hér á landi. Prátt fyrir mikinn áhuga á viðfangsefninu alpjóðlega hefur nálgunin verið gagnrýnd par sem hún er m.a. talin vera of lýsandi og kenningarlega veik. Hafa ekki embættismenn og stjórnmálamenn stolið hugmyndum frá hvor öðrum í aldir? Í ár verður Efnahags- og framfarastofnunin (OECD) 60 ára. Ísland er eitt af stofnaðildarríkjunum og pví kominn tími til að rýna petta langa samstarf sem íslensk stjórnsýsla hefur átt við OECD. Tilgangur pessarar greinar er að fjalla um starfsemi OECD og meta áhrif hennar á íslenska stefnumótun. Í fyrsta hluta greinarinnar er annars vegar fjallað um forvera OECD sem var Efnahagssamvinnustofnun Evrópu (OEEC) og hvernig hún lagði grunninn að pví hvernig OECD starfar í dag. Hins vegar er farið ítarlega yfir hlutverk og skipulag OECD og pær áskoranir sem stofnunin hefur staðið frammi fyrir
\end{abstract}


á undanförnum áratugum. Í öðrum hluta er aðferðin stefnuyfirfærsla skoðuð nánar. Aðferðin er skilgreind auk pess sem fjallað er um helstu leikendur. Tilraun er gerð til að ramma inn helstu afbrigði stefnuyfirfærslna og rætt er um sjálfviljuga og pvingaða yfirfærslu. Að lokum er fjallað um pátttöku Íslands á vettvangi OECD. Til að meta að hvaða leyti íslensk stjórnvöld nýta sér afurðir OECD við stefnumótun hér á landi er stuðst við gögn úr árangurskönnunum stofnunarinnar.

Efnisorð: OECD; stefnuyfirfærsla; stefnumótun; stofnun; afurðir.

\section{Policy transfer: OECD impact on policy making in Iceland}

\section{Abstract}

International organizations such as the OECD, the United Nations, the International Monetary Fund, and the World Bank are known for spreading ideas, values and policies around the world. In the 90 s academic interest in policy transfer increased significantly and researchers tried to create a framework for the approach, explaining why a policy transfer is taking place, under what circumstances, at what stage, etc. Policy transfer as a method has been studied in great detail in recent years by a number of scholars, although not very much in Iceland. Despite great interest in the method, the approach has been criticized for being too descriptive and theoretically weak. Haven't officials and politicians copied ideas from each other for centuries? This year, the Organization for Economic Co-operation and Development (OECD) will be 60 years old. It is therefore timely to study the impact OECD has had on Icelandic public administration after 60 years of partnership. The objective of this analysis is to combine a discussion on OECD's activities and assess its impact on Icelandic public policy making. The first part of the article discusses the predecessor of the OECD, the Organisation for European Economic Co-operation (OEEC), and how it laid the foundations for how the OECD operates today. Furthermore, the current role and structure of the OECD is discussed as well as the tools it has at its disposal to impact policy making in member states. In the second part, the policy transfer method is examined in detail. The definition of the term is discussed, while an attempt is made to identify who is normally involved in policy transfer etc.? Is policy transfer voluntary or coercive? An attempt is made to frame the main variants of policy transfer and discuss ways to identify whether a policy transfer has occurred. Finally, Iceland's participation in OECD work is discussed and an attempt is made to analyse data from the OECD's Programme of Implementation Reports (PIR) to assess the extent to which the Icelandic government is utilizing the organization outputs for shaping policy making.

Keywords: Policy transfer; OECD; policy making; voluntary/coercive; PIR; committees. 


\section{Inngangur}

Pann 14. desember 1960 undirrituðu fulltrúar 16 Evrópulanda stofnsáttmála nýrrar stofnunar ásamt fulltrúum Bandaríkjanna og Kanada. Stofnunin sem um ræðir er Efnahags- og framfarastofnunin, alla jafnan pekkt undir ensku skammstöfuninni OECD. Ísland var meðal stofnríkja OECD en stofnunin á rætur að rekja allt til ársins 1948 pegar Efnahagssamvinnustofnun Evrópu (OEEC), forveri OECD, var stofnuð m.a. til að halda utan um framkvæmd Marshall aðstoðarinnar í Evrópu eftir seinni heimsstyrjöldina. Pann 30. september næstkomandi verða liðin 60 ár frá pví stofnunin tók formlega til starfa. Í greininni er fjallað í stuttu máli um próun stofnunarinnar og pær áskoranir sem stofnunin hefur staðið frammi fyrir undanfarna áratugi.

Alpjóðastofnanir á borð við OECD, Sameinuðu pjóðirnar, Alpjóðagjaldeyrissjóðinn, Alpjóðabankann og fleiri hafa í síauknum mæli staðið að baki útbreiðslu hugmynda, gilda og stefna um allan heim. Pessar alpjóðastofnanir hafa bæði bein áhrif á innlenda sérfræðinga með sínum stefnum og lánaskilyrðum (AGS og Alpjóðabankinn) og óbein áhrif í gegnum pær upplýsingar sem frá peim koma, jafnan á ráðstefnum peirra eða í útgefnum skýrslum (Dolowitz \& Marsh 2000).

Stefnumótun og stefnuyfirfærsla (e. policy transfer) var frá upphafi eitt meginverkefni Efnahagssamvinnustofnunar Evrópu (OEEC), sem hafði verið falið að samhæfa jafningjaúttektir (e. peer review) á efnahagsstefnum ríkja áður en Marshallaðstoð til ríkis var sampykkt. Petta var „pvingandi“ yfirfærsla á stefnu (Aubrey 1967). Pegar OECD leysti OEEC af hólmi árið 1961 hélt pess starfsemi áfram, p.e. jafningjaúttektir á efnahags- og fjármálastefnum ríkja. Pessi starfsemi var síðar útvíkkuð pannig að hún náði til annarra sviða eins og stjórnsýslunnar, ríkisfjármála, félags- og umhverfislegra málaflokka auk annarra. Nánar er fjallað um pessa starfsemi í greininni. Með nýju stofnuninni árið 1961 var hins vegar ekki lengur um að ræða pvingunarferli, par sem OECD hafði ekki lengur pað hlutverk að stýra afgreiðslu fjárhagsaðstoðar til handa aðildarríkjum. Uppleggið í starfsemi OECD var frjálst samstarf ríkja á jafnréttisgrundvelli (Aubrey 1967). OECD hefur pví frá stofnun hvorki haft „gulrætur“", svo sem aðstoð eða fjármuni, né „refsivönd“, svo sem viðurlög, sektir eða önnur slík pvingandi úrræði til að beita í samskiptum við aðildarríki sín.

Stefnuyfirfærsla (e. policy transfer) hefur verið tískuorð í heimi stjórnsýslufræðanna sl. prjá áratugi. Баð má flokka með hugtökum eins og nýskipan í opinberum rekstri sem flestir kannast við. prátt fyrir pað hefur viðfangsefnið verið mjög lítið rannsakað hérlendis. Рað sama má segja um OECD pó jafnan sé vísað til stofnunarinnar pegar fjallað er um nýskipan í opinberum rekstri en stofnunin var í forsvari fyrir pá stefnu um langt skeið.

Í pessari grein eru færð rök fyrir pví að OECD sé sú alpjóðastofnun sem hefur hvað mesta pverfaglega tengingu við íslenska stjórnsýslu og á pað bæði við um stofnanir og ráðuneyti. Flestar aðrar alpjóðastofnanir hafa mun afmarkaðri nálgun eða skilgreind viðfangsefni. Má hér nefna stofnanir eins og Alpjóðaheilbrigðismálastofnunina, Alpjóðaviðskiptastofnunina eða Atlantshafsbandalagið.

Megintilgangur greinarinnar er að rannsaka áhrif OECD á íslenska stefnumótun, 
heilt yfir en einnig á mismunandi málaflokka hins opinbera. Stefnuyfirfærsla er eitt megintæki OECD og pví nærtækast að meta að hvaða leyti Ísland hefur tileinkað sér áherslur og stefnur OECD. Рað gerist t.a.m. pegar stofnunin setur fram tillögur vegna úttektar sem stofnunin ynnir af hendi fyrir íslensk stjórnvöld. Eða að frumkvæði opinberra aðila hér á landi sem nýta sér hugmyndir, tillögur, áherslur og fleira sem birt er í ótal útgefnum afurðum á vegum OECD. Stefnuyfirfærsla sem aðferð er rýnd og tilraun gerð til að skilgreina pverfaglega fjölprepa nálgun við útfærslu hennar. Að hluta til er skoðað við hvaða aðstæður hentugt er að huga að stefnuyfirfærslu og hvernig. Megináherslan er pó á málaflokka, umfang og spönn stefnuyfirfærslu.

Í pessari rannsókn er stuðst við gögn og kannanir sem OECD hefur gert sem hluti af árangursstýringu stofnunarinnar. Pau gögn sem hvað mest er unnið með í pessari grein eru fengin úr nokkrum könnunum OECD sem gerðar hafa verið síðastliðinn áratug. Ekki hefur áður verið unnið úr pessum gögnum hérlendis. Einnig er stuðst við gögn úr upplýsingagrunni OECD, m.a. til að greina umsvif Íslands á vettvangi OECD.

\section{Efnahags- og framfarastofnunin í 60 ár}

Evrópa var í sárum eftir síðari heimsstyrjöld. Verksmiðjur voru rústir einar og samgöngur lamaðar. Ljóst var að pað tæki nokkurn tíma að rétta við atvinnulíf og efnahag Evrópuríkjanna sem verst höfðu orðið úti í styrjöldinni. Dað var Marshall, utanríkisráðherra Bandaríkjanna, er kom fram með tillögu um stórfellda aðstoð Bandaríkjanna við Evrópu og er aðstoðin kennd við hann. Til pess að dreifa Marshallfénu og vinna að framkvæmd hinnar nýju stefnu um efnahagssamvinnu tóku 18 Vestur-Evrópuríki pátt í stofnun OEEC (Guðmundsson 1964).

OEEC hjálpaði Evrópuríkjunum til að rétta úr kútnum fjárhagslega eftir hörmungar styrjaldarinnar og hafði á fyrstu árum sínum fyrst og fremst pað hlutverk að stjórna Marshallhjálpinni. Annað mikilvægt hlutverk stofnunarinnar var að gera verslun innan Evrópu frjálsari og náði hún miklum árangri á pví sviði. Pá vann OEEC ekki síður gott verk í Greiðslubandalaginu (EPU) og með Evrópska gjaldeyrissamningnum (EMA), sem tók við pegar Greiðslubandalagið var lagt niður. Stofnunin vann einnig að frekari samvinnu ríkisstjórna í efnahags- og gjaldeyrismálum, aukinni framleiðni í aðildarríkjunum og stuðlaði að bættum lífkjörum (Guðmundsson 1962).

Próun OEEC pau 13 ár sem stofnunin var starfandi skiptir máli í sögulegu samhengi. OECD er byggt á grunni OEEC, p.e. peim vinnubrögðum og skipulagi sem stofnunin hafði komið á fót á mjög skömmum tíma. OEEC hafði t.a.m. komið á fót nefndum sem gaf aðildarríkjunum tækifæri til að rýna til gagns framkvæmd ríkja á Marshall aðstoðinni heima fyrir. Ríkin voru ekki tilbúin að flytja vald til embættismannanefnda heldur var komið á fót nefndarfyrirkomulagi par sem ríkin sjálf áttu sæti. Í dag, eins og fjallað verður nánar um síðar í greininni, eru pessar nefndir á priðja hundrað (Carrol \& Kellow 2011).

En af hverju OECD? Í lok sjötta áratugarins var farið að velta vöngum yfir tilgangi OEEC par sem pað hafði i fyrsta lagi uppfyllt meginhlutverk sitt, sem var að halda utan um framkvæmd og eftirfylgni með Marshallaðstoðinni. Í öðru lagi má segja að OEEC 
hafði tekist að stuðla að verulegri efnahagsuppbyggingu í Evrópu á pessum tíma. Í priðja lagi voru efasemdir meðal aðildarríkjanna hvort stofnunin gæti yfir höfuð haldið áfram í ljósi ágreinings sem upp hafði komið pegar OEEC ríkin skiptust í tvær fylkingar og stofnuðu annars vegar Efnahagsbandalag Evrópu síðar Evrópusambandið og hins vegar EFTA. Ýmsar hugmyndir voru á borðinu, m.a. að útvíkka hlutverk NATO svo pað gæti tekið yfir OEEC. Á endanum var ákveðið að endurskipuleggja OEEC með formlegri pátttöku Bandaríkjanna og Kanada stutt af Bandaríkjastjórn en pessi ríki höfðu verið hálfgerðir áheyrnarfulltrúar (e. associate members) fram að pessu. Litið var svo á að OECD væri ekki ný stofnun heldur endurskipulögð OEEC með fullri pátttöku Bandaríkjanna og Kanada. Ný stofnun ætti að horfa fram á við, efla samstarf sitt við próunarríki og horfa til ríkja í öðrum heimsálfum, sérstaklega Japans (Carrol \& Kellow 2011).

Eins og fram hefur komið var sáttmálinn undirritaður 14. desember 1960 í París og undirritaði Gylfi P. Gíslason viðskiptaráðherra hann fyrir Íslands hönd. Ekki var sérstök nefnd innan OEEC sem fjallaði um sjávarútvegsmál og dró pað mjög úr gagnsemi stofnunarinnar að mati Íslendinga. Við undirritun sáttmálans í desember 1960 gerði íslenska sendinefndinni pví athugasemd við pá stöðu mála. Lagði sendinefndin til að nýja stofnunin setti á fót nefnd til að fjalla um framleiðslu og sölu fiskafurða. Tillagan var sampykkt (Alpýðublaðið 1960). Hafa ber í huga að árið 1960 voru íbúar Íslands aðeins 177.000 og hefur íbúafjöldinn meira en tvöfaldast á síðastliðnum 60 árum. Ísland býr jafnframt við mun fjölbreyttara hagkerfi nú en pá, pegar pað reiddi sig aðallega á fiskútflutning.

Sáttmálinn skyldi staðfestur af pingum samningsríkjanna. Í lok september 1961 höfou öll ríki, sem undirrituðu Parísarsáttmálann staðfest hann nema prjú (Ítalía, Holland og Luxemborg). Sáttmálinn tók engu að síður gildi og stofnunin tók til starfa. Í fyrrgreindum ríkjum voru pað ýmis formsatriði sem töfðu staðfestingu (Guðmundsson 1962).

\subsection{OECD: Próun og áskoranir}

Seint á sjöunda áratugnum og snemma á peim áttunda, eða fljótlega eftir stofnun OECD varð Evrópusamruninn meiri og dýpri. Um tíma var litið á Evrópubandalagið sem meginkeppinaut OECD (Camps 1975). Á pessum árum naut stefnumótunarvinna OECD verulegs lögmætis af nokkrum ástæðum. Í fyrsta lagi var pað að hluta til byggt á „innherjasið“. Samstaða um stefnu var að hluta til innbyggð inn í vinnuferlið, með samkomulagi milli fulltrúa stofnunarinnar og aðildarríkjanna (Pal 2012). Að auki renndi efnahagsleg staða aðildarríkja OECD stoðum undir pær hugmyndir að OECD væri að deila „,réttum“ stefnum. Í stuttu máli var efnahagslegur árangur talinn til marks um lögmæti stefnu OECD. Eftir hrun Sovétríkjanna, ríkti ákveðin ró innan OECD, eins og próunin hefði réttlætt lögmæti stefnu stofnunarinnar (Clifton \& Díaz-Fuentes 2014).

Eftir hrun kommúnismans purfti stofnunin í auknum mæli að réttlæta tilvist sína. Ekki var talin lengur pörf fyrir klúbb kapítalískra hagkerfa. Í raun mætti OECD sinni mestu áskorun frá stofnun. Í áratugi var OECD pekkt sem „klúbbur ríkra pjóða“ og helsta aðalsmerki stofnunarinnar var framleiðsla hagfræðilegra gagna og greininga. 
Traust og orðspor markaðist af efnahagslegum árangri aðildarríkjanna. Á 10. áratug síðustu aldar fóru yfirburðir OECD-ríkjanna í efnahagslífinu minnkandi, par sem hagvöxtur færðist afgerandi til austurs og suðurs (Quah 2011). Stofnunin gerði sér grein fyrir pví að vægi aðildarríkjanna í heimshagkerfinu væri að dragast saman á meðan tiltekin nýríki voru að vaxa meira en meðal aðildarríki OECD. Mahbubani (2012) fullyrti аð OECD væri að líða undir lok eðа аð verða „Sunset Organization“. Stofnunin tók eftir pví að pað var fjöldi nýrra iðnríkja í örum vexti og að pau væru að ná mikilvægri fótfestu í efnahag heimsins. Ef spár OECD í kringum aldamótin reyndust réttar voru yfirburðir aðildarríkja OECD, sem hlutdeild af landsframleiðslu og viðskiptum í alpjóðahagskerfinu, að fara halloka (Clifton \& Díaz-Fuentes 2014). Reyndar áætluðu rannsóknir OECD að árið 2030 myndu meðlimir OECD ekki lengur vera með stærstan hlutann af vergri landsframleiðslu, mælt í kaupmáttarhlutfalli (e. PPP). Detta hafði lækkað úr 60 prósent árið 2000, í 51 prósent árið 2010 og átti eftir að lækka enn frekar eða í 43 prósent árið 2030 skv. einni spánni (OECD 2010). Nýrri spár fyrir OECD eftir Andrew Mold (2010) gera ráð fyrir að aðildarríki OECD verði með um 30 prósent af vergri landsframleiðslu í PPP árið 2030.

Umbætur hjá stofnuninni hófust í byrjun aldarinnar og tóku á sig ýmsar myndir, p. á m. umbætur á fjárframlögum til stofnunarinnar; samkomulag um að ráðast í takmarkaða stækkun til fjögurra landa; ,,útrásar“ verkefni sem ætlað var að stuðla að frekara samstarfi í öllum heimsálfum, skuldbinding um að taka virkari pátt í sameiginlegum verkefnum með öðrum alpjóðastofnunum og áætlun til að eiga nánara samstarf með fimm lykilríkjum (OECD 2007). Aukin pátttaka eða Enhanced Engagement áctlunin samanstóð af tilraun til að vinna náið með fimm ríkjum sem meðlimir OECD höfðu sampykkt sem mikilvæg: Brasilíu, Kína, Indlandi, Indónesíu og Suður-Afríku. Markmiðið var að vinna náið með pessum ríkjum og fella pau smám saman að stefnufyrirkomulagi aðildarríkja OECD með pað fyrir augum að pau gætu að lokum orðið aðilar að stofnuninni (OECD 2007).

Á pessum árum pegar OECD var að undirbúa stækkun og víðtækara samstarf við framangreind ríki skellur á efnahagskreppa með peim afleiðingum að fjöldi ríkja, p. á m. aðildarríki OECD ákveða að falla frá fyrri stefnu um nýskipan í ríkisrekstri (NPM) sem hafði verið eitt helsta flaggskip stofnunarinnar um langt skeið. ó rannsóknir OECD á NPM bendi til pess að árangur hafi náðst í peirri viðleitni að gera stjórnsýslu skilvirkari, gagnsærri, árangursmiðaðri og sveigjanlegri með aukinni áherslu á parfir borgaranna pá hafði aðferðin sætt vaxandi gagnrýni ekki síst vegna pess að margar af peim breytingum sem gerðar voru í nafni NPM voru innleiddar án pess að gæta að pví hvaða áhrif pær höfðu á gildi sem einkenna opinbera stjórnsýslu (Samhent stjórnsýsla 2010). Sá vandi sem stofnunin stóð frammi fyrir í kjölfar efnahagshrunsins 2008 er að einhverju leyti einkennandi fyrir pær áskoranir sem stofnunin stendur jafnan frammi fyrir. Баð er að stofnunin kann að vera of einsleit í hugsun, stefnur of mikið mótaðar af svipuðum ríkjum með svipaða sýn á pað hvernig heimsmálin eiga að ganga fyrir sig. Pví kann stofnuninni að reynast erfitt að ná til ríkja utan peirrar kúlu sem aðildarríkin eru í og fá aðra sýn og umræðu um aðrar nálganir. 
Dátt fyrir að pessi fimm ríki hafi ekki enn orðið meðlimir að OECD hefur stofnunin stækkað um priðjung frá lokum kalda stríðsins og telur í dag 37 aðildarríki. Nokkur ríki eru í dyragættinni og er núverandi aðildarríki að meta hvort tilefni sé til pess að bjóða pau velkomin. Petta eru ríki í Suður-Ameríku og Austur-Evrópu og svipar til peirra ríkja sem gerst hafa meðlimir á síðustu premur áratugum. Hlutfall af vergri landsframleiðslu mælt í kaupmáttarhlutfalli (PPP) hefur haldist nokkuð stöðugt síðastliðinn áratug og var í kringum 50\% árið 2017. ${ }^{1}$ Dátttaka OECD á vettvangi G20 ríkja hefur aukist til muna fyrir tilstuðlan núverandi framkvæmdastjóra Angel Gurría pannig að eftir hefur verið tekið. OECD hefur tekið að sér ýmsa grunnvinnu í aðdraganda G20 funda sem hefur styrkt stofnunina alpjóðlega. Síðast en ekki síst má nefna krísurnar tvær, annars vegar fjármálahrunið 2008 og kórónuveirufaraldurinn 2020/2021. Krísur hafa skapað vettvang fyrir nýjar lausnir og alpjóðastofnanir eins og OECD grípa fegins hendi tækifærið til að bjóða pær fram, ekki aðeins í págu ríkja eða alpjóðasamfélagsins, heldur einnig til að viðhalda mikilvægi sínu og hagsmunum (Pal 2014).

\subsection{Starfsemi OECD: Hlutverk og markmið}

Hlutverk OECD er að styðja við og ýta undir pau stefnumál sem bætt geta efnahagslega og félagslega velferð ríkja á heimsvísu. Stofnunin er vettvangur par sem ríkisstjórnir koma með tillögur að lausnum við sameiginlegum vandamálum, deila reynslu sinni og skilgreina bestu leiðirnar til að bæta lífskjör. Markmiðin eru prípætt:

- Að ná sem mestum og varanlegustum hagvexti og sem hæstu atvinnustigi í aðildarríkjunum.

- Að stuðla að efnahagspróun jafnt í aðildarríkjunum sem utan peirra.

- Að leggja sitt af mörkum til vaxtar og próunar heimsviðskipta (Carrol \& Kellow 2011).

Áherslur stofnunarinnar geta hins vegar tekið breytingum. Stofnunin parf að vera sveigjanleg svo hún geti brugðist við breyttum aðstæðum hverju sinni og búið sig undir mismunandi sviðsmyndir í framtíðinni. Hver framkvæmdastjóri leggur vanalega línurnar sem aðildarríkin taka afstöðu til. Einnig er árlegur ráðherrafundur svokallaður Ministerial Council Meeting (MCM) par sem áherslur og forgangsmál eru sampykkt. Segja má að ráðherrafundirnir byggi hver ofan á annan fremur en að áherslum fyrra árs sé kastað fyrir róða. Starfsemi OECD samanstendur af premur ásum, sá fyrsti er ráðið par sem jafnan situr einn fulltrúi frá hverju ríki. Annar eru skrifstofur stofnunarinnar par sem starfa á bilinu 2500-3000 starfsmenn frá öllum aðildarríkjunum. Að lokum eru pað nefndirnar sem skrifstofur stofnunarinnar halda utan um en fundir nefndanna eru jafnan sóttir af sérfræðingum viðkomandi sviða, p.e. sérfræðingum í ráðuneytum og stofnunum frá aðildarríkjunum sjálfum, sjá nánar mynd. 


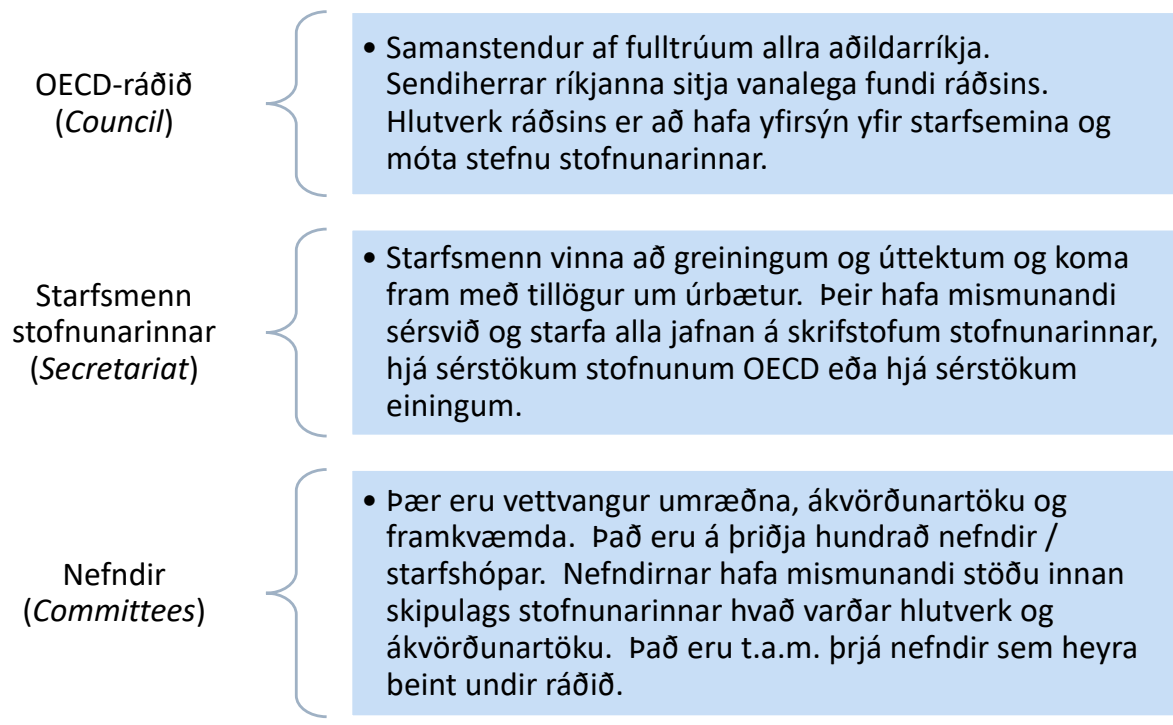

Mynd 1. Skipulag OECD í hnotskurn

Á mynd 2 má sjá nánari yfirlit yfir skipulag OECD og hvernig pví er háttað, með ráðið (e. Council) sem æðsta ákvörðunartökuaðila innan stofnunarinnar. Í kjölfarið koma prjár lykilnefndir, p.e. ExCo, BC og ERC. Bað eru 37 svokallaðar Level I Substantive Committees, petta eru meginákvörðunartökuaðilar í hverjum málaflokki fyrir sig. Undir hverri nefnd á myndinni starfa nokkrar undirnefndir/vinnuhópar og eru pær sóttar af fulltrúum aðildarríkja og funda að jafnaði 1-2 sinnum á ári. Á pessum fundum kynna OECD (Secretariat) og ríkin sjálf ýmsar stefnumótandi afurðir og taka ákvarðanir um hvert skuli stefna á komandi misserum. 
Pétur Berg Matthíasson

STJÓRNMÁL

STJÓRNSÝSLA

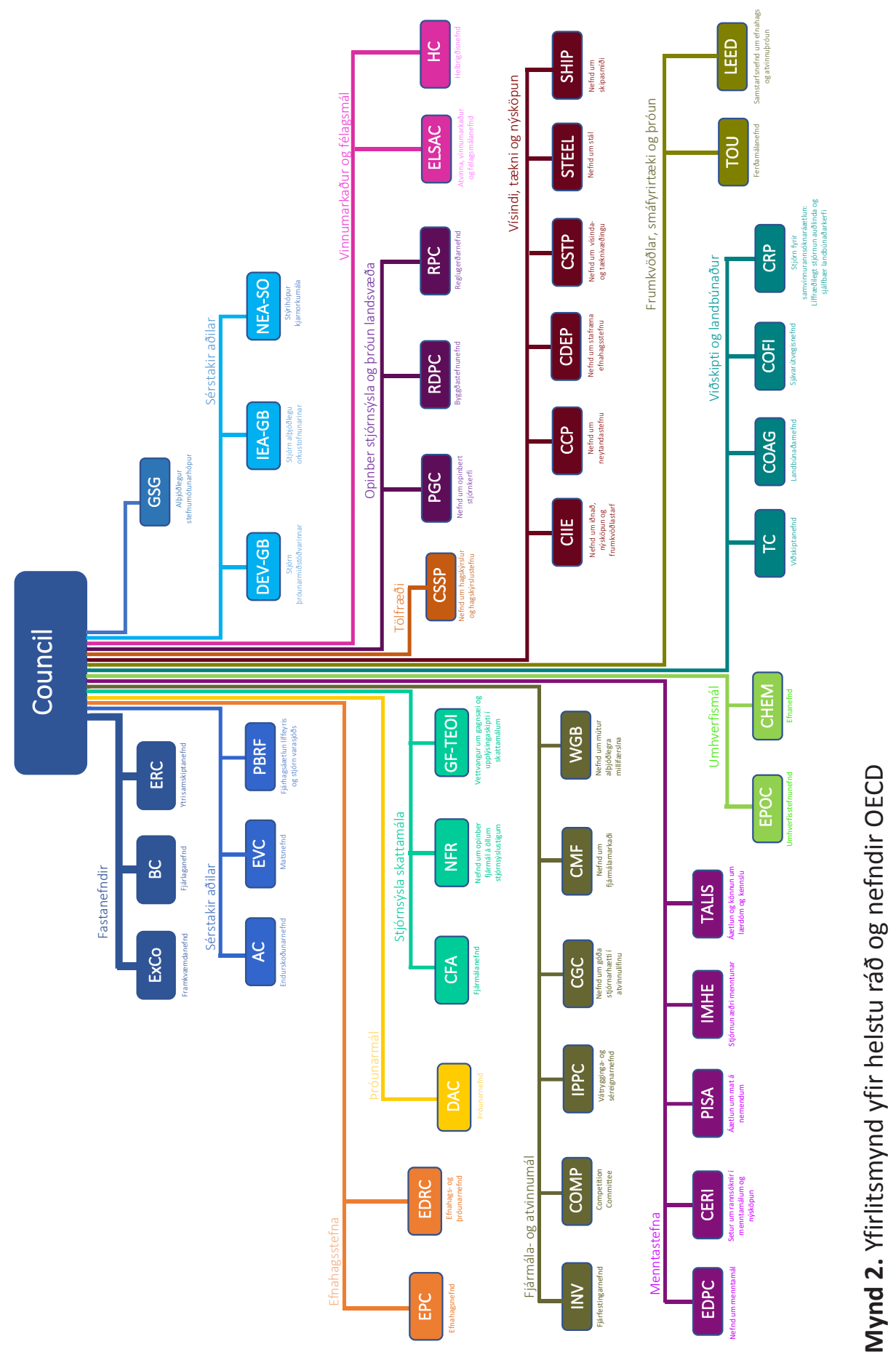


Fulltrúar aðildarríkja sem sækja fundi nefnda og vinnuhópa OECD gera pað í meginatriðum í prenns konar tilgangi; 1) að fá upplýsingar um pað helsta og nýjasta sem er að gerast í tilteknum málaflokki, s.s. að fá leiðbeiningar, ráðgjöf, upplýsingagjöf o.fl., 2) efla tengsl við kollega frá öðrum ríkjum, 3) deila reynslu og pekkingu með öðrum. Fulltrúar fastanefnda hafa annað hlutverk en peim ber að tryggja hagsmuni sinna ríkja og stofnunarinnar og gera peir pað m.a. með pví að reyna að hafa áhrif á heildarstefnu stofnunarinnar.

\section{Stefnuyfirfærsla: Aðferðir og leiðir}

Liðin eru rúm 30 ár síðan greina mátti fyrst vaxandi áhuga meðal fræðimanna í stjórnsýslufræðum á að rannsaka stefnuyfirfærslu (e. policy transfer). Dýðingin er e.t.v. ekki góð en hún er að einhverju leyti samheiti yfir önnur hugtök sem notuð hafa verið til að skilgreina sambærilega framkvæmd eins og samleitni stefnu / policy convergence (Coleman 1994), stefnudreifingu / policy diffussion (Majone 1991), stefnumiðlun / policy learning (P. Haas 1992) og stefnulærdóm / lesson drawing (Rose 1991). Öll pessi hugtök fjalla í meginatriðum um stefnuyfirfærslu, p.e. ,ferli par sem pekking á stefnum, stjórnsýslufyrirkomulagi, stofnunum o.fl. á einum tíma og eða á einum stað er notað við próun stefnu, mótun stjórnsýslufyrirkomulags eða gerð stofnana á öðrum tíma og eða öðrum stað (Dolowitz \& Marsh 1996).

Rannsóknir á alpjóðavæðingunni benda til pess að pað sé ógjörningur að einangra efnahag pjóðar frá alpjóðlegum efnahagslegum áhrifum (Parsons 1996). Tækniframfarir síðustu 25 ára hafa stuðlað að auknum skoðanaskiptum pvert á landamæri og hefur almenningur nú betri tækifæri en nokkurn tímann í mannkynsögunni til að skiptast á skoðunum og pekkingu. Eins og fram hefur komið hafa alpjóðastofnanir gegnt veigamiklu hlutverki við stefnuyfirfærslu frá lokum seinni heimsstyrjaldarinnar, m.a. með tilkomu Bretton Woods stofnanna og OEEC. Samanlagt hafa pessar breytingar orðið til pess að stefnumótendur afla sér í auknum mæli pekkingar í öðrum löndum um skipulag stofnana, stefnumála og áætlana. Рað parf ekki að koma á óvart að umfjöllun um stefnuyfirfærslu sl. prjá áratugi hefur aukið áhuga fræðimanna og nema á viðfangsefninu. Samt sem áður hafa tiltölulega fáir skoða ferlið beint; pað er meira verið að lýsa flutningi hugmynda eða stefna milli landa en ekki reynt að greina og skýra pá ferla sem í hlut eiga (Dolowitz \& Marsh 2000).

Dolowitz og Marsh (1996) hafa leitt tilraunir innan breskrar stjórnmálafræði til að próa líkan um stefnuyfirfærslu. Peir hafa í meginatriðum rammað inn hugtök. Sá rammi getur verið gagnlegur en hann býður pó upp á gagnrýni. Með honum má engu að síður kortleggja ferla stefnuyfirfærslu með hlutlægum hætti. Prátt fyrir yfirgripsmikla umfjöllun um hugtakið hefur greining á stefnuyfirfærslu ekki verið nægjanlega vel skýrð og er erfitt að segja að hér sé um kenningu að ræða en pað myndi krefjast pess að próað yrði orsakalíkan byggt á röð fullyrðinga sem hægt væri staðfesta eða véfengja með gögnum (Evans \& Davies 1999). Dolowitz og Marsh (1996) halda hins vegar réttilega fram að pað sé mikilvægt að hafa skýran ramma fyrir stefnuyfirfærslu. Til pess að geta greint stefnuyfirfærslu vísa peir í fimm heimildir sem hægt er að notast við til að staðfesta yfir- 
færslu stefnu eður ei: Fjölmiðla, skýrslur, ráðstefnur, heimsóknir og yfirlýsingar stjórnvalda. Í pessari rannsókn er m.a. stuðst við niðurstöður kannanna til að staðfesta hvort yfirfærsla hafi átt sér stað.

Stefnuyfirfærsla er „,ferli par sem pekking um stefnur, stjórnsýslufyrirkomulag, stofnanir o.fl. á einum tíma og eða á einum stað er notað við próun stefnu, mótun stjórnsýslufyrirkomulags eða skipulag stofnana á öðrum tíma og eða á öðrum stað“ (Dolowitz \& Marsh 1996). Ferlið „stefnuyfirfærsla“ felur í sér sjálfviljuga „yfirfærslu, tilraun til að draga úr „pvingunarflutningi“‘, p.e. pegar önnur stjórnvöld eða alpjóðleg stofnun hvetur eða jafnvel neyðir stjórnvöld til að taka upp stefnu. Dolowitz og Marsh (1996) fjalla almennt um mjög breitt svið af pví sem hægt er að flytja, par á meðal stefnumarkmið, skipulag, tæki eða stjórnsýsluaðferðir, skipulag stofnana, hugmyndafræði, hugmyndir, viðhorf og hugtök auk lærdóms af mistökum annarra.

Eins og fram hefur komið hefur aðferðin verið gagnrýnd, m.a. fyrir einfaldleika sinn par sem tilfærslu er nánast líkt við vélrænan flutning frá A til B. एað sé hins vegar sjaldnast raunin auk pess sem pað sem er fært yfir sé heldur ekki mjög skýrt. Dessi umræða tengist jafnframt hugmyndinni um árangursríka framkvæmd sem kann einnig að vera nokkuð óskýr. Jafnvel pó yfirfærslan sé talin árangursrík pá kann hún að mistakast par sem samhengið og fólkið er öðruvísi og stefnan gengur hreinlega ekki upp á öðrum stöðum (Lendvai \& Stubbs 2007; Dolowitz \& Marsh 2012; Stone 2017).

рessi umræða er áhugaverð í tengslum við „ein stærð hentar öllum“ stefnur og áherslur alpjóðastofnana eins og AGS og Alpjóðabankans síðastliðna áratugi. Umræðan á Íslandi í kjölfar fjármálakrísunnar var einmitt um áhyggjur af nálgun AGS og hvort stofnunin myndi leggja til stefnur og áherslur sem gengið hefðu misvel í ýmsum próunarríkjum eða hvort AGS myndi taka mið af stöðunni hér. Flestir eru á pví að nálgun AGS hafi endanum verið óvenjuleg, séríslensk og ekki hefðbundin yfirfærsla.

\subsection{Lántakendur, lánveitendur og umboðsmenn}

pegar kemur að stefnuyfirfærslu vakna ótal spurningar. Af hverju taka aðilar pátt í yfirfærslu á stefnu? Hverjir eru lykilaðilar sem taka pátt í yfirfærslunni? Hvað er flutt? Hvaðan er dreginn lærdómur? Hverjir eru helstu áfangar í flutningi? Hvað takmarkar eða auðveldar stefnuflutningsferlið? Ýmsar fyrri rannsóknir hafa ýmist beint eða óbeint haldið pví fram að til séu lántakendur og lánveitendur pegar kemur að stefnuyfirfærslu og að pessi hlutverk breytist sjaldan (Robertson 1991; Robertson \& Waltman 1992; Rose 1993). Petta er pó ekki algild regla; oft draga lönd sem eru lánveitendur lærdóm á meðan lönd sem eru flokkuð sem lántakendur starfa sem fyrirmynd annarra stjórnmálakerfa (Dolowitz \& Marsh 2000).

Fræðimenn hafa gert tilraunir til að fjalla um svokallaða umboðsmenn og hlutverk peirra við stefnuyfirfærslu. Spurningar eru settar fram eins og hver eða hvað er skilgreindur sem umboðsmaður flutningsins, hvað vilja peir með flutningi, hvernig ætla peir að framkvæma flutning, í págu hvers og hvers vegna? Hugtakið umboðsskrifstofa er einnig notað en umboðsmaður er talinn nauðsynlegur fyrir jafnt sjálfviljuga sem og pvingaða stefnuyfirfærslu. Til að skerpa á matinu leitast fræðimenn eftir vísbendingum 
um að eitthvað hafi verið flutt. Sumir vilja gera greinarmun á mjúkum yfirfærslum (hugmyndum, hugtökum, viðhorfum) og hörðum flutningum (verkefni og aðgerðir) og draga ályktanir af eðli og umfangi pess flutnings sem átt hefur sér stað (Evans \& Davies 1999)

Í fræðunum er greint á milli tveggja nálgana sem undirrót stefnuyfirfærslu. Annars vegar frjálsan flutning og hins vegar pvingaðan flutning. Eðlilegt er að spyrja hvort stefnuflutningur kunni að vera mismunandi eftir pví hvar hann á sér stað innan stefnumótunarferilsins. Er t.d. líklegra að pað sé hvetjandi flutningur pegar stefnan er á undirbúningsstigi? Standa umboðsmenn fyrir ólíkum stefnuyfirfærslum? Reyna t.d. stjórnmálamenn að afrita „erlend“ líkön á meðan embættismenn vinna að pví að próa ný verkefni sem samanstanda af blöndu af mismunandi hugmyndum og verkefnum? Dolowitz \& Marsh 2000).

\subsection{Fjölbreytileiki stefnuflutnings}

Stefnuyfirfærsla er ekki allt eða ekkert ferli. Dó að hvert tilvik geti falið í sér mismunandi samsetningu ferla (og/eða umboðsmenn), eru í grundvallaratriðum fjórar mismunandi leiðir við flutning stefnu: afritun (e. copying), sem felur í sér beinan og alhliða flutning; eftirlíking (e. emulate), sem felur í sér flutning á hugmyndunum á bak við stefnuna eða áxtlunina; samtenging (e. combinations), sem fela í sér samblöndu af nokkrum mismunandi stefnum; og innblástur (e. inspiration), par sem stefna í annarri lögsögu getur hvatt til stefnubreytingar, en par sem niðurstaða byggir ekki endilega á upprunalegu stefnunni (Dolowitz \& Marsh 2000; Rose 1993). Frá pví pessar fjórar meginleiðir voru kynntar til leiks hafa fleiri bæst við. Par á meðal eitthvað sem kallað er neikvæð yfirfærsla eða pegar verið að taka mið af einhverju sem fór úrskeiðis annars staðar. Вað getur reynst erfitt að rannsaka svokallaða neikvæða yfirfærslu, p.e.a.s. að einhver gerir ekki $\mathrm{X}$ af pví pað tókst illa upp annars staðar. Hins vegar er pessi umræða mjög lífleg enda fjölda mörg dæmi til um stefnur sem náðu ekki fram að ganga. En fyrir vikið er nánast hægt að kalla hvað sem er einhvers konar form af stefnuyfirfærslu (Stone 2017).

Hver stefnuyfirfærsla er breytileg og háð páttum eins og hverjir taka pátt 1 ferlinu og hvar í stefnumótunarferlinu flutningur á sér stað. Pannig kunna stjórnmálamenn að leita „skyndilausna“ og treysta pannig á afritun eða eftirlíkingu. Embættismenn gæetu hins vegar haft áhuga á að blanda mismunandi stefnum saman. Svo kann eftirlíking að skipta mestu máli i upphafi vinnunnar, en afritun eða samblanda nokkurra mismunandi stefna eða áætlana á síðari stigum (Dolowitz \& Marsh 2000).

Mismunandi hvatar kunna að liggja að baki stefnuyfirfærslu. Ef farið er í stefnuyfirfærslu á tímum félagslegs, pólitísks og efnahagslegs stöðugleika er t.d. líklegt að flutningurinn sé frjáls. Ef pað er hins vegar pólitísk kreppa eða óstöðugleiki í landinu kann stefnuyfirfærsla að hafa orðið vegna einhvers konar pvingunar. Ef pað er alpjóðleg kreppa, svo sem efnahagshrun kunna lykilpátttakendur í ferlinu að finna fyrir prýstingi til að taka pátt í stefnuyfirfærslu. Detta kann einnig að gerast ef alpjóðleg hreyfing styður við tilteknar hugmyndir eins og útbreiðslu einkavæðingar o.s.frv. Ennfremur, í stríðum eða strax í kjölfar stríðs, er líklegra að sá sem tapaði sé tilneyddur af andstæðingnum til að pess að taka upp annars konar stjórnmálakerfi, stefnur, áxtlanir eða jafnvel skipulag 
stofnana. Dæmi um slíkt var stjórnarskrá Japans og Pýskalands sem gerð var eftir síðari heimsstyrjöldina (Dolowitz \& Marsh 2000).

Sjálfviljug tilfærsla eða pvingun er einnig hægt að skoða út frá leikendum í alpjóðasamfélaginu. Afritun eða eftirlíking virðist vera meira pvingandi á forsendum Evrópusambandsins meðan alpjóðavæðingin er talin leiða af sér sjálfviljugri yfirfærslu í formi innblásturs. Prátt fyrir fjöldann allan af rannsóknum er erfitt að alhæfa um pessi mál. Hér skiptir nálgunin m.a. máli, hvað er pað sem kallar á tilfærslu, hvað er verið að færa yfir og hverjar eru líklegar afleiðingarnar fyrir samfélagið (Benson \& Jordan 2011)?

Í tilfelli alpjóðastofnunar eins og OECD má segja að hún séu bæði lánveitandi og umboðsmaður. Stefnur og áherslur stofnunarinnar verða pó ekki til í tómarúmi og eiga flestar rætur að rekja eitthvert. Рær purfa jafnframt að samrýmast áherslum stofnunarinnar áður en pær eru skoðaðar, metnar og endurútfærðar fyrir önnur ríki.

\section{Pátttaka Îslands á vettvangi OECD}

Hver skrifstofa innan OECD hefur ákveðnar meginnefndir og voru pær kallaðar Level I Substantive Committees hér að framan. Undir pær falla aðrar nefndir og vinnuhópar OECD, allt að 300 talsins. Pessar nefndar sampykkja til tveggja ára mjög ítarlega verkefnaáætlun (e. PWB) par sem fram koma áherslur í málaflokknum. Pó grunnurinn að verkefnaáxtlununum sé mótaður af fyrri yfirlýsingum og vinnu OECD á sér stað ítarleg umræða meðal aðildarríkja um hvaða áherslur skuli setja málaflokki. Bureau eða stjórnir nefnda gegna oft veigamiklu hlutverki í pessu starfi og hittast jafnvel sérstaklega til að ræða drög að verkefnaáætlun (e. PWB). Skiljanlega eru stóru pjóðirnar mjög virkar í pessu ferli og reyna að tryggja að OECD vinni í samræmi við peirra áherslur og forgangsmál.

Fastanefnd Íslands hjá OECD samanstendur af sendiherra og sérfræðingi. Ísland á sæti í OECD ráðinu par sem alla jafnan sitja sendiherrar aðildarríkja OECD. Peir taka ákvarðanir í sameiningu um vinnuáætlanir og framlag ríkja til stofnunarinnar. Fulltrúar fastanefndarinnar hafa eftirlit með störfum ýmissa nefnda OECD sem og starfsemi próunarsamvinnusetursins, Alpjóðafjarskiptasamtakanna (ITF) og Kjarnorkumála-stofnunarinnar (NEA), sem Ísland er aðili að. Fastanefndin gegnir mikilvægu samskiptahlutverki og er oft og tíðum í hlutverki tengiliðs á milli skrifstofa OECD og íslenskra stjórnvalda. Hún fer fyrir hönd Íslands í marghliða samningaviðræðum, vísar á málaflokka pegar stjórnvöld hyggjast leita sér sérpekkingar og leitast við að miðla tillögum OECD á Íslandi. Detta gerir fastanefndin til að tryggja gott samstarf og að Ísland njóti sem mest ávinnings af starfi OECD.

Íslenska stjórnsýslan er fámenn og pví er henni mikilvægt að hafa aðgang að peim upplýsingabrunni sem úttektir OECD eru, eins og peirri jafningjarýni og upplýsingamiðlun sem á sér stað milli aðildarríkjanna á vettvangi stofnunarinnar. Engin önnur alpjóðastofnun gefur út sambærilega tölfræði um jafn yfirgripsmikið svið hagtalna og OECD. Stofnunin hefur yfir að skipa færustu sérfræðingum á hverju sviði. Á tveggja ára fresti gefur stofnunin út skýrslu um íslensk efnahagsmál par sem byggt er á fundum við fulltrúa ólíkra hópa hér innanlands, greiningu og mati sérfræðinga OECD á stöðu 
mála. Í skýrslunum er að finna tillögur um aðgerðir sem fulltrúar aðildarríkjanna hafa haft tækifæri til að rýna og fjalla um. OECD getur ekki knúið á um framkvæmd tillagnanna og er jafningjaprýstingur sú leið sem farin er til að ýta á að farið sé eftir tillögum stofnunarinnar. Í samskiptum við ríki er m.a. fjallað um pá meinbugi sem kunna að vera á pví að hrinda vel meintum tillögum til úrbóta í framkvæmd.

Pátttaka Íslands á vettvangi OECD nær yfir fjölda ólíkra sviða. Pátttakan er hins vegar undir Íslendingum sjálfum komið. Ekkert aðildarríki parf að taka pátt og vera virkt í öllum nefndum og stofnunum OECD. Ísland sem smáríki hefur forgangsraðað og má segja að fulltrúar íslenskra stjórnvalda séu sérstaklega virkir í sumum nefndum par sem Ísland hefur hag af pví að vera með. Sem aðildarríki hefur Ísland aðgang að öllum nefndum, gögnum og upplýsingum OECD. Greiningar OECD á stöðu mála hér á landi takmarkast pó að mestu við efnahagsmálin (e. Economic outlook og survey). Dá er ákvarðanir stundum teknar um nánara samstarf á öðrum sviðum gegn viðbótar kostnaði (t.d. PISA kannanir). Ísland hefur einnig verið mjög virkt í Próunarsamvinnunefnd OECD (DAC) og tók nýlega sæti í pví. Dað mun pví í framtíðinni reglulega fá úttektir á framkvæmd íslenskrar próunaraðstoðar sem stuðlar að faglegu aðhaldi, pannig má bæta árangur af íslenskri próunaraðstoð.

Flestar nefndir/vinnuhópar sem íslenskir fulltrúar sitja í heyra undir almennar skrifstofur OECD á ólíkum fagsviðum, sjá nánar mynd 3. Einnig eru starfræktar sérstakar stofnanir og aðrar einingar undir formerkjum OECD. Ísland hefur oft verið í nánu samstarfi við pessa aðila, sérstaklega Financial Action Task Force (FATF). Pað er alpjóðlegur vinnuhópur um aðgerðir gegn peningapvætti og fjármögnun hryðjuverka. FATF skilaði skýrslu um stöðuna hér á landi í pessum málaflokki vorið 2018. ${ }^{2}$

Skrifstofur
(Department /
directorate)
- Development Co-operation Directorate
- Economics Department
- Directorate for Education and Skills
- Directorate for Employment, Labour and
- Social Affairs
- Centre for Entrepreneurship, SMEs, Regions
and Cities
- Environment Directorate
- Directorate for Financial and Enterprise
Affairs
- Directorate for Public Governance
- Directorate for Science, Technology and
Innovation
- Statistics and Data Directorate
- Centre for Tax Policy and Administration
- Trade and Agriculture Directorate
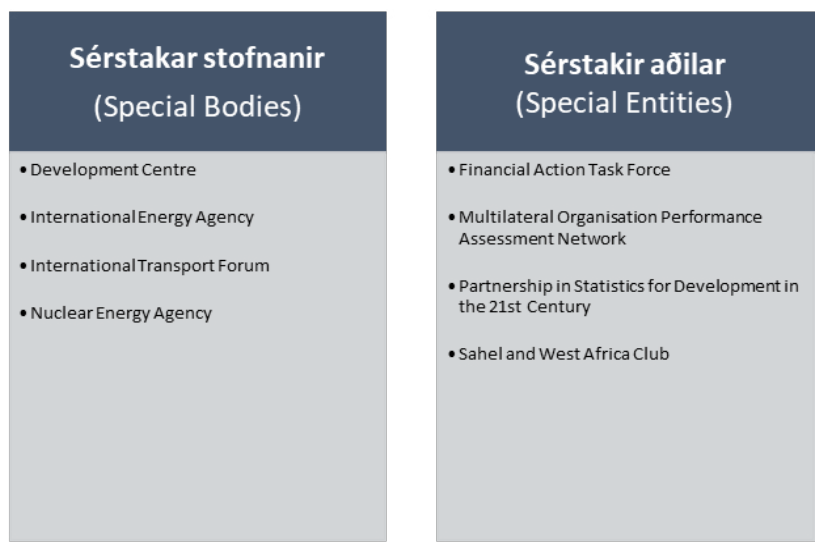

\section{Mynd 3. Yfirlit yfir skrifstofur, sérstakar stofnanir og sérstakir ađilar OECD}

Ísland hefur stýrt ýmsum nefndum og/eða stýrinetum í gegnum tíðina. Nýlega fóru full- 


\section{STJÓRNMÁL \\ \& \\ STJÓRNSÝSLA}

trúar Íslands með formennsku í Network of Senior Officials from Centres of Government (CoG) og Network on Gender Budgeting. Um er að ræða annars vegar stýrinet sem samanstendur af æðstu fulltrúum stjórnkerfismiðja (CoG) og sitja jafnan ráðuneytisstjórar forsætisráðuneyta í pessum hópi. Hins vegar er um vinnuhóp sérfræðinga um kynjaða fjárlagagerð аð ræða sem fellur undir nefnd fjárlagastjóra OECD ríkja (Senior Budget Officials / SBO). Báðar pessar nefndir teljast til málaflokka undir Directorate of Public Governance (Opinberir stjórnarhættir). Sumar nefndir hafa stjórnir (e. bureau) og átti Ísland um nokkurt skeið fulltrúa í stjórn Regulatory Committee eða nefnd um lagasetningu ríkja OECD.

\subsection{Pátttaka í nefndarstarfi}

Íslenskir opinberir starfsmenn taka reglulega pátt í störfum stofnunarinnar á ári hverju, par á meðal við greiningu á stöðu efnahagsmála á Íslandi. Aðrir málaflokkar sem Ísland tekur virkan pátt í á vegum OECD telur m.a. menntamál, skattamál, heilbrigðismál, samkeppnismál, ferðamál og atvinnumál. Pátttaka Íslands nær til um 200 ólíkra efnispátta innan stofnunarinnar og er OECD ein af peim alpjóðastofnunum sem íslensk stjórnsýslu vinnur hvað mest með.

Sumir pessara einstaklinga sækja fundi hjá fleiri en einni nefnd á hverju ári og sumar nefndir funda oftar en einu sinni á ári. Flestir pessir fundir eru haldnir í höfuðstöðvum OECD i París. Fulltrúar fastanefndarinnar sitja hins vegar langflesta fundi OECD. Nánar tiltekið fundi ráðsins, fundi lykilnefnda stofnunarinnar (ExCo, BC og ERC) auk ýmissa annarra nefndafunda að beiðni íslenskra stjórnvalda, pó peir heyri undir málaflokka annarra ráðuneyta en utanríkisráðuneytisins. Рað má pví ætla að fulltrúi frá Íslandi sitji fundi á vegum OECD a.m.k. annan hvern dag í eðlilegu árferði.

Á mynd 3 hér að neðan má sjá fjölda fulltrúa frá stofnunum og ráðuneytum íslenska ríkisins sem sóttu fundi á premur tímabilum, 2013-2014, 2015-2016 og 2017-2018. Hér er einungis um fjölda einstaklinga að ræða sem sóttu fundi, sumir peirra sóttu fleiri en á einn fund á umræddu tímabili. Á tímabilinu 2013-2014 voru 104 íslenskir pátttakendur í fundum á vegum OECD. Á árunum 2015-2016 voru peir orðnir 123 en á síðasta tímabili voru peir nærri 200. Fjármála- og efnahagsráðuneytið er pað ráðuneytið sem á í hvað nánustu samstarfi við skrifstofur og stofnanir OECD. Einnig sækja starfsmenn utanríkisráðuneytisins, forsætisráðuneytisins, Seðlabankans og menntamálaráðuneytisins reglulega fundi hjá OECD. 


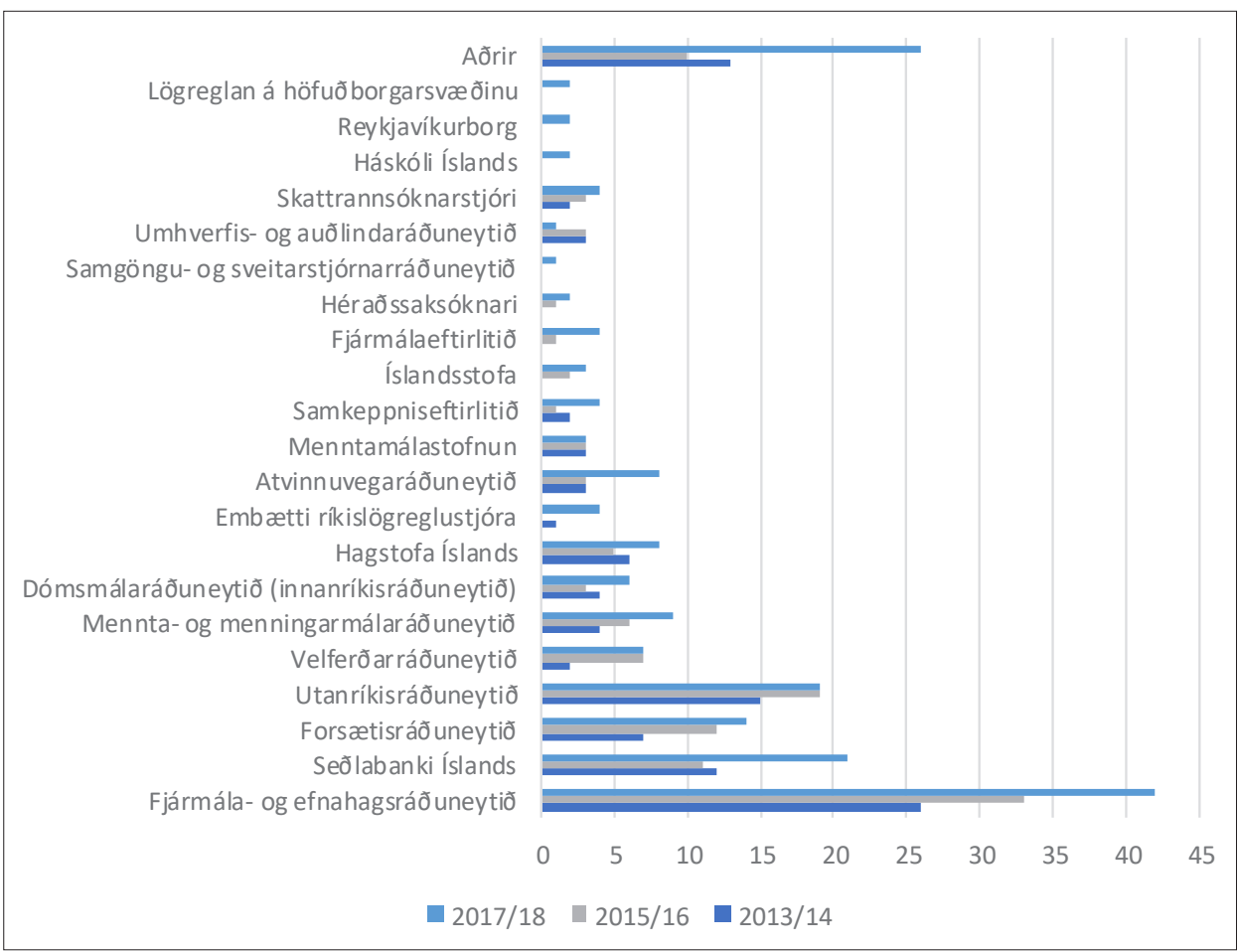

Mynd 4. Fjöldi opinberra starfsmanna sem sóttu fundi OECD á premur tímabilum, 2013-2014, 2015-2016 og 2017-2018

Degar nánar er skoðað hvaða fundir voru sóttir kemur í ljós að íslenskir fulltrúar sitja einna helst fundi á vegum Public Governance Directorate. Málaflokkar Public Governance Directorate falla að stærstum hluta undir stjórnarmálefni fjármála- og efnahagsráðuneytisins og forsætisráðuneytisins sjá mynd 5. Má hér nefna fjárlagagerð, opinbera nýsköpun, opinber innkaup, málefni stjórnkerfismiðja, framfylgd laga og reglna, siðareglur, umbótamál o.s.frv. Ljóst er að Íslendingar sækja einnig reglulega fundi um skattamál, heilbrigðismál, ferðapjónustu, próunarmál og fjárfestingarmál. 


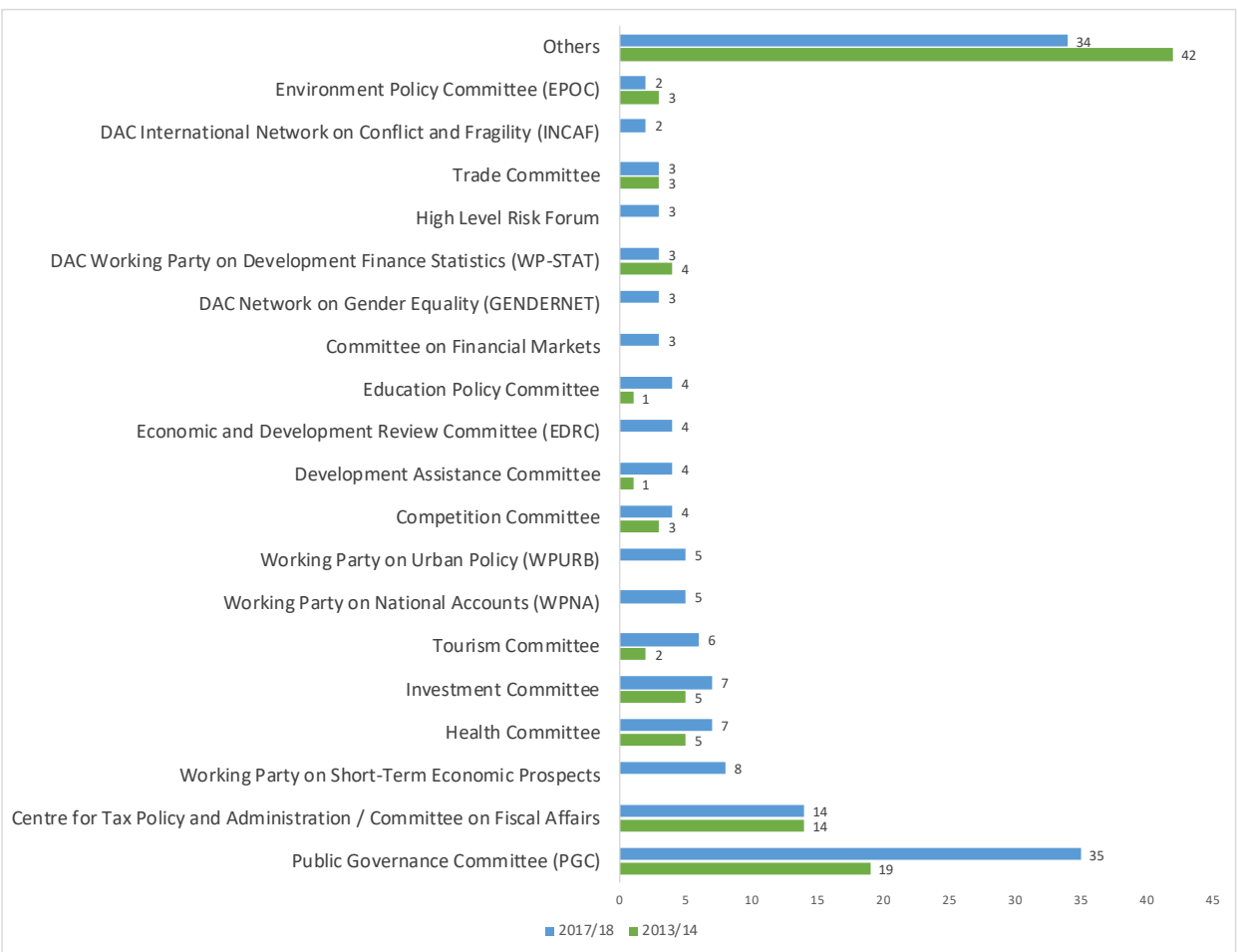

Mynd 5. Fjöldi einstaklinga sem sóttu fundi nefnda / vinnuhópa árin 2013-2014 og 2017-2018

\subsection{Mat á notkun afurđa OECD (Programme Implementation Report / PIR)}

Áhrif og staða OECD í hinu alpjóðalega kerfi grundvallast að stórum hluta á gæðum, notkun og áhrifum vinnu hennar og afurða. Áætlun um framkvæmd verkefna (e. Programme Implementation Report / PIR) er aðferðafræði sem OECD beitir til að fylgjast með og greina áhrif stofnunarinnar meðal aðildarríkja. Áxtlunin (PIR) er hluti af sampættu stjónnunarkerfi OECD. Um er að ræða umfangsmikið mat sem tekur til allra aðildarríkja OECD og nær yfir allt efni I. hluta vinnuáætlunarinnar. PIR hófst árið 2003 og var 2017-18 matið níunda alhliða frammistöðumatsskýrslan par sem metin var notkun og áhrif afurða (skýrslur, leiðbeiningar, greiningar o.s.frv.) skv. vinnuáætlun (e. Programme of Work and Budget / PWB) OECD. Tíunda matið, 2019-2020 er nú 1 undirbúningi. PIR er ómissandi hluti af árangursmiðaðri fjárlagagerð og stjórnun og gerir OECD ábyrgt gagnvart aðildarríkjum. PIR skoðar sérstaklega kostnað, magn, gæði, notkun, áhrif og hvort lokið er við verkefni innan tiltekinna tímamarka. Mikilvægt er að hafa í huga samhengið pegar kemur að mati á notkun og áhrifum afurða par sem aðildarríki finna fyrir mismikilli pörf til að nota afurðir stofnunarinnar. 
Framkvæmd PIR grundvallast á að púsundir notendur afurðanna eru beðnir um að veita endurgjöf á gæði, notkun og áhrif afurða með pví að taka pátt í könnun. Svör pátttakenda eru síðan send fastafulltrúum ríkjanna sem einnig svara spurningunum. Niðurstöðurnar eru kynntar OECD ráðinu par sem fulltrúar allra aðildarríkja sitja, fjárlaganefnd OECD auk pess sem eftirfylgninefnd nýtir sér upplýsingarnar við sína vinnu.

\subsection{Mat íslenskrar stjórnsýslu á afurðum OECD}

OECD sendir PIR kannanir að jafnaði út annað hvert ár, 2017, 2019 o.s.frv. Deir sem taka pátt eru peir sem hafa sótt fundi hjá stofnuninni. Einnig peir sem fastanefndin 1 París í samráði við íslensk stjórnvöld telja að kunni að hafa nýtt sér afurðir OECD á sl. tveimur árum. Á Íslandi telur pessi listi pví oftast færri en hundrað einstaklinga. Aðeins hluti peirra svarar könnuninni en spurningarnar snúa fyrst og fremst að peim afurðum sem stofnunin hefur gefið út á tímabilinu en pað eru að jafnaði 150-200 afurðir árlega. Á tímabilinu 2015-2016 mátu starfsmenn í íslenskri stjórnsýslu 41 afurð sem er um rúmlega 25\% af verkáætlunum (PWB) OECD. Meðaltalið í öðrum aðildarríkjum var 60\% fyrir sama tímabil. Á tímabilinu 2017-2018 mátu starfsmenn íslenskrar stjórnsýslu 33 afurðir sem er um 22\% af verkáætlunum (PWB) OECD. Meðaltalið í öðrum aðildarríkjum var 59\% fyrir sama tímabil, sjá mynd.

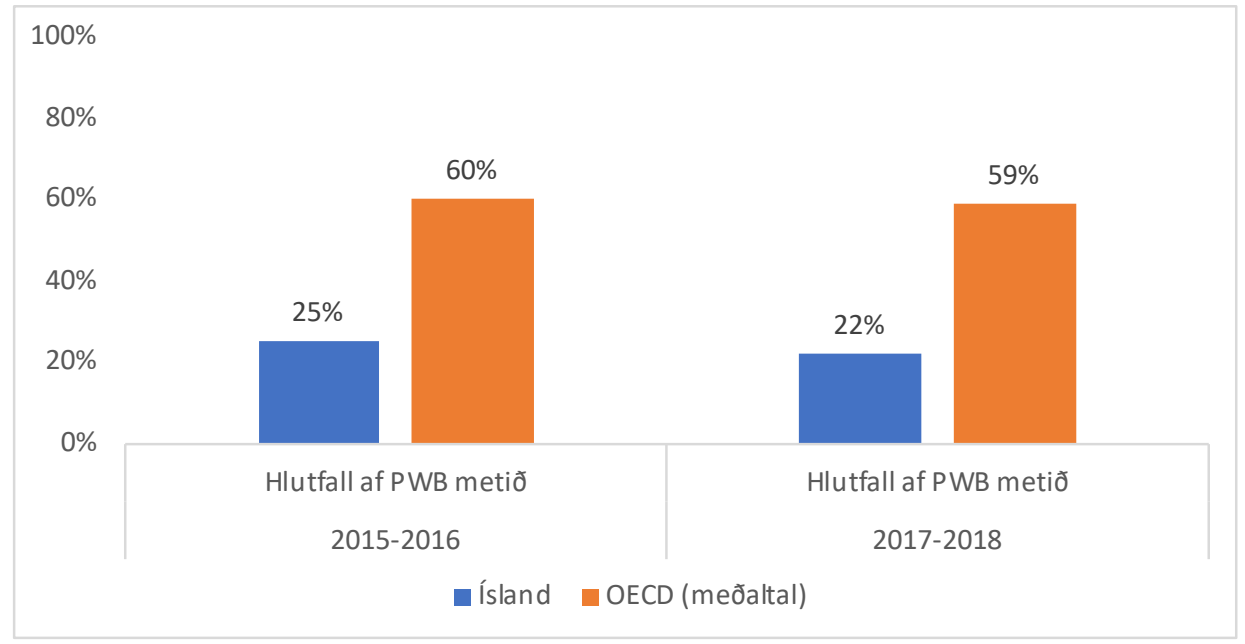

Mynd 6. Hlutfallslegt mat á verkáætlunum OECD 2015-2016 og 2017-2018

Hlutfallið hér á landi er frekar lágt í stóra samhenginu og í samanburði við OECD meðaltalið. Sé hins vegar tekið mið af pví að Ísland parf að forgangsraða málum parf svo ekki að vera. Engu að síður gefur petta til kynna að pað sé stór hluti af afurðum OECD sem Ísland nýtti sér ekki á umræddu tímabili. Hafa ber í huga að ríki hafa misjafna pörf fyrir afurðir OECD á hverjum tíma og ræðst pað m.a. af umbótapörf og umbótavilja, stöðu stjórnmála, kosningum o.s.frv. OECD gerir sér grein fyrir pví að eftirspurnin eftir afurðunum er mismikil meðal ríkja á hverjum tíma. 
Degar skoðað er hvaða afurðir íslensk stjórnsýsla hefur nýtt sér á síðastliðnum árum kemur í ljós að prír flokkar skera sig úr. Annars vegar 2.1. mannauður og félagsauður en undir pennan flokk falla menntamál og önnur hæfni á vinnumarkaðnum. Đað er 4.3 sem fjallar um ýmsa opinbera- og efnahagslega stjórnarhætti og $1.1 \mathrm{sem}$ fjallar um efnahagslegt eftirlit, p. á m. efnahagslegar greiningar OECD sem gerðar eru annað hvert ár. Aftur á móti má sjá að á milli tímabila hefur dregið úr notkun nokkurra afurða OECD, t.a.m. á heilbrigðissviðinu, sjá mynd 7.

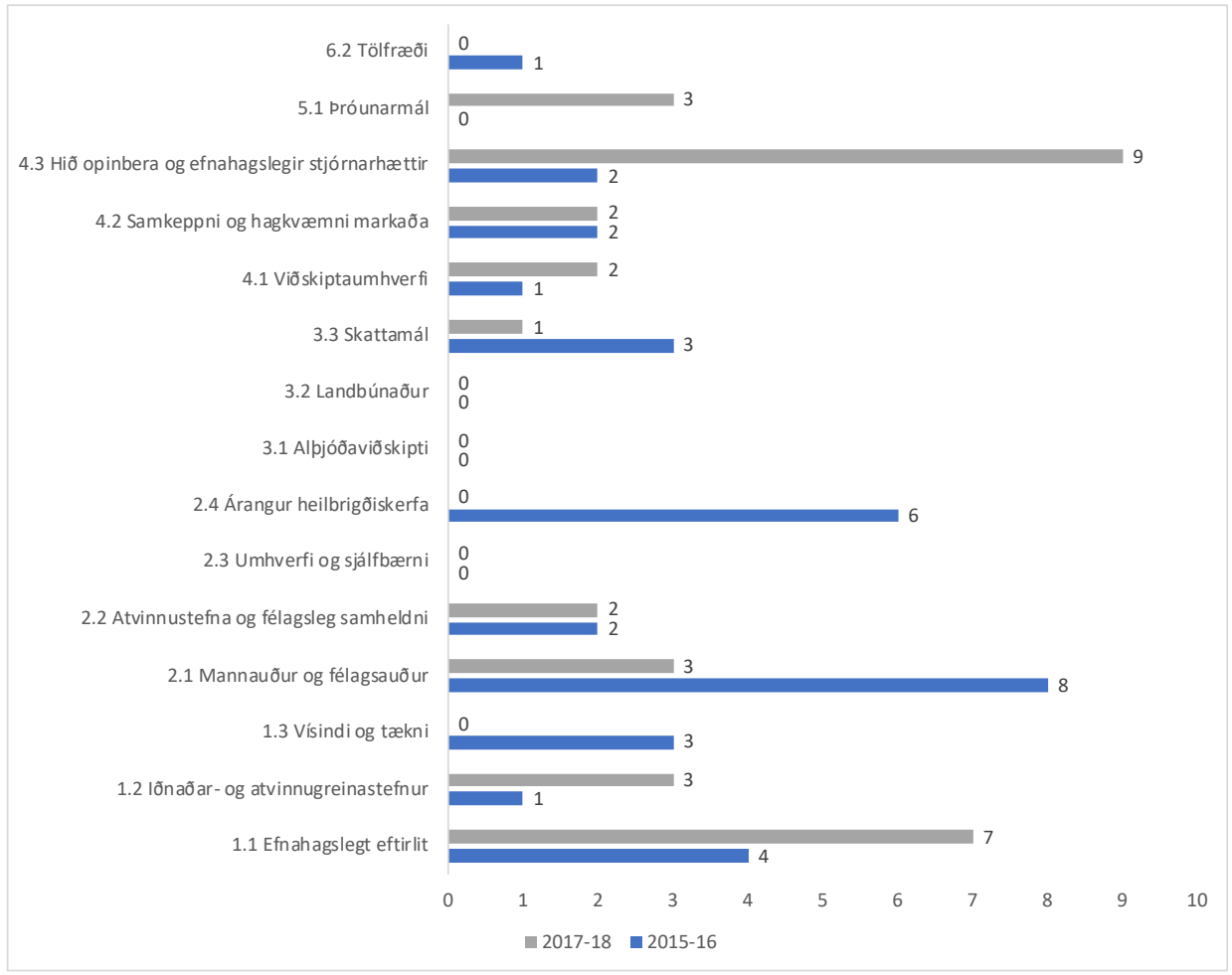

\section{Mynd 7. Notkun íslenskra fulltrúa á afurđum OECD eftir yfirflokkum}

Sjá má að málaflokkarnir falla að stærstum hluta undir verksvið fjármála- og efnahagsráðuneytisins. Afurðir eins og efnahagslegt eftirlit fela í sér greiningar m.a. á stöðu ríkisfjármála. Oft eru pemu sem koma inn á aðra málaflokka eins og menntun, hæfni, samkeppnishæfni o.fl. ${ }^{3}$ Afurðir sem tilheyra 4.3 um opinbera- og efnahagslega stjórnarhætti telur málaflokka sem lúta einnig að stefnumótun og stjórnsýsluskipulagi. Má gera ráð fyrir að forsætisráðuneytið sé jafnframt að nýta afurðir par undir. Segja má að afurðir OECD hafi einna mest áhrif á stefnumótun í fjármála- og efnahagsráđuneytinu. Đær eru pó jafnframt notaðar við stefnumótun í öðrum ráðuneytum, sjá dæmi í töflu 1. 


\section{Tafla 1. Stefnuflutningur: frá OECD til Íslands - dæmi}

1) Lög um breytingu á lögum nr. 90/2003 um tekjuskatt, međ síđari breytingum (afleiðuviðskipti, vatnsveitur og fráveitur, arđsúthlutun til eigenda félaga, millilandasamruni, milliverđlagning, sérstakur fjársýsluskattur, eindagi). ${ }^{4}$

pađ voru sérstakar milliverđlagsreglur innleiddar í lög um tekjuskatt međ 8. gr. laga nr. 142/2013 sem tók gildi 1. janúar 2014. Með pví ákvæđi voru leiðbeiningar OECD um milliverđlagningu innleiddar, pótt tilvísun til peirra hafi verið fjarlægð úr ákvæđinu með 3. gr. laga nr. 33/2015. Pá gaf ráđuneytið út reglugerð nr. 1180/2014 um skjölun og milliverđlagningu í viđskiptum tengdra lögađila pann 16. desember 2014, sem tók gildi 1. janúar 2015 og byggir á áđurnefndum leiðbeiningum OECD.

2) Frumvarp til laga um breytingu á ýmsum lögum til einföldunar á regluverki. ${ }^{5}$

Á síđustu misserum hefur Efnahags- og framfarastofnunin (OECD) unnið ađ gerđ samkeppnismats á lögum og reglum sem gilda um byggingariðnað og ferđapjónustu samkvæmt samningi við atvinnuvega- og nýsköpunarráđuneytið. Niðurstađa verkefnisins var nýlega kynnt í skýrslu OECD um samkeppnismat á regluverki ferðapjónustu og byggingariðnađar. par kom fram að reglubyrđi atvinnustarfsemi hér á landi er töluvert meiri en í peim löndum sem við berum okkur alla jafna saman við og ađgangshindranir á markađi víđa. í frumvarpi pessu eru lagðar til breytingar sem eru til samræmis við pá vinnu sem unnin hefur verið af OECD og miðar að pví að fella niður óparfa leyfisveitingar, draga úr ađgangshindrunum að mörkuðum og efla umhverfi virkrar samkeppni

3) Vönduð löggjöf: Yfirlit yfir 145. löggjafarping (2015-2016)

OECD hefur verið í fararbroddi á alpjóđavettvangi undanfarin ár í peirri viđleitni að hvetja pjóđir til ađ huga að gæðum laga og reglna. Í pví ljósi miđar starf OECD að pví ađ bæta efnahagslega stöđu ríkja og möguleika peirra á að bregđast við breytingum. Byggist pað á peirri forsendu að vandað regluverk sé nauđsynlegt til ađ tryggja blómlegan efnahag pjóđa ásamt pví að styrkja velferđarkerfi og umhverfismál í ríkjunum. Skrifstofa löggjafarmála hefur undanfarin ár fylgst međ pví sem fram fer á vettvangi OECD um bættan undirbúning við gerđ laga og reglna. Pannig hafa fulltrúar skrifstofunnar sótt fundi í nefndum á pess vegum (e. Regulatory Policy Committee) sem haldnir eru tvisvar á ár.

4) Siđareglur fyrir ráđherra og starfsfólk Stjórnarráđsins ${ }^{7}$

Við gerð pessara reglna hefur verið stuðst við viđmið fyrir góđa starfshætti ríkisstarfsmanna sem fjármálaráđuneytið gaf út árið 2006, pær siðareglur sem pegar eru fyrir hendi í ráđuneytum hér á landi, og margvíslegar leiðbeiningar OECD og fleiri alpjóđlegra stofnana, svo sem Evrópuráđsins. pá hefur fyrirkomulag pessara mála í öđrum ríkjum veriđ haft til hliđsjónar.

5) Skýrsla OECD um samkeppnismat á umgjörđ ferđapjónustu og byggingariðnađar ${ }^{8}$ Ræđa Páls Gunnars Pálssonar, forstjóra Samkeppniseftirlitsins

Niðurstöđur ítarlegrar greiningarvinnu par sem stjórnvöld og hagsmunaađilar hafa, undir styrkri leiđsögn OECD, komið auga á leiðir til pess að skapa ferđapjónustu og byggingariðnađi betri umgjörð sem er til pess fallin að efla pessar greinar til framtíđar, til hagsbóta fyrir neytendur og almenning, til hagsbóta fyrir atvinnulífið og til hagsbóta fyrir íslenskt efnahagslíf í heild sinni.

Með pví ađ setja saman pessa skýrslu og kynna hana er mikilvægum áfanga nád, en sigurinn er ekki unninn. Рað parf að koma tillögunum í framkvæmd. pað er stóra áskorunin sem við stöndum frammi fyrir. Ekki bara fyrir stjórnvöld, heldur líka hagsmunaađila. pađ er nefnilega ekki víst ađ peir séu allir hrifnir af öllum tillögunum. pað er hins vegar mikilvægt að allir horfi á stóru myndina, fremur en einstaklingsbundna hagsmuni. pá mun petta ganga vel.

Notkun afurða er greind nánar niður eftir pví hvort hún er; 1) notuð til að breyta stefnum, 2) notuð sem tilvísun við mótun stefna, 3) hvort hún hafi tækifæri til að hafa áhrif á mótun stefna, 4) ekki notuð. Eins og sjá má á mynd átta að neðan er notkun 


\section{STJÓRNSÝSLA}

afurða á Íslandi mjög stefnumiðuð. Afurðir voru notaðar i 67\% tilfella sem grundvöllur til umræðna um stefnumótun árin 2017-2018 samanborið við 66\% meðaltal allra OECD ríkja. Hlutfallið er aðeins (6\%), pegar spurt er að hve miklu marki afurðirnar voru notaðar sem grundvöllur stefnubreytinga árin 2017-2018. Íslendingar nýta sér afurðirnar ekki verr en önnur OECD ríki, sjá mynd 8. Рað ætti ekki að koma á óvart hvert umfangið еða „,breidd“ flutningsins er mikil par sem umboð OECD nær til mun fjölbreyttari málaflokka en t.d. Alpjóðaviðskiptastofnunin gerir sem er með áherslu fyrst og fremst á viðskipti. Hins vegar kann umfang flutnings frá sértækari alpjóðastofnunum eins og Alpjóðaviðskiptastofnuninni að einkennast af meiri „dýpt“ í peim skilningi að nýir meðlimir skuldbinda sig að gangast við fjöldann allan af samningum innan eins málaflokksins, viðskipti (Carrol 2013).

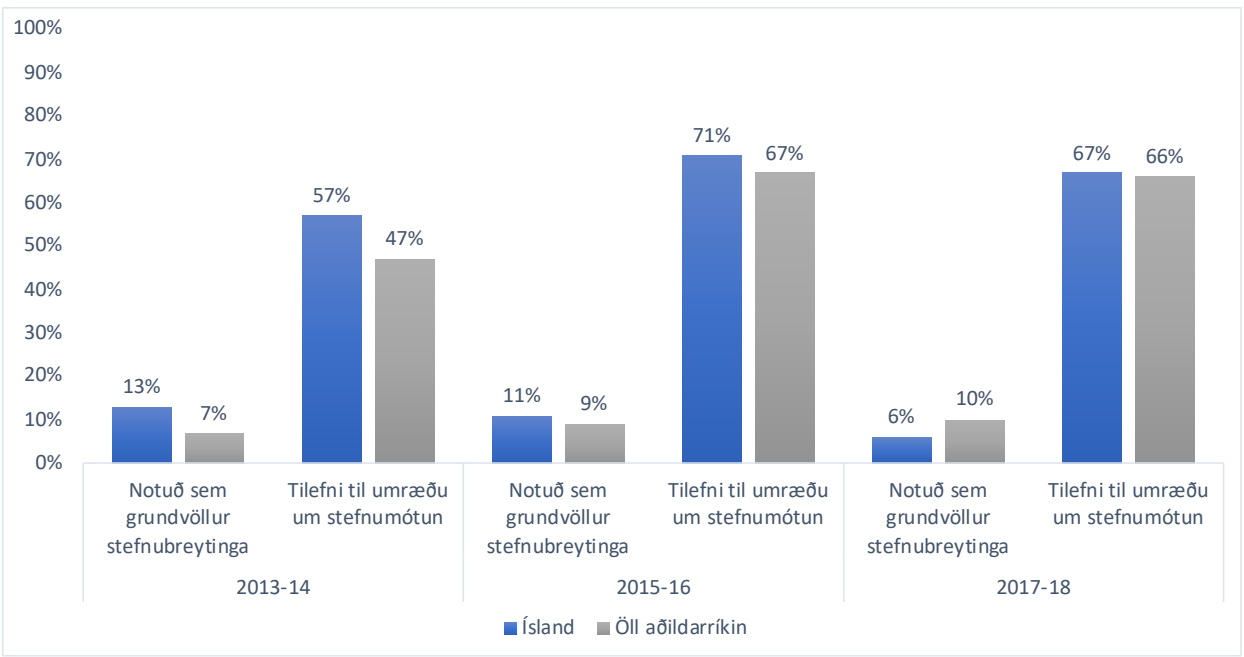

\section{Mynd 8. Notkun afurđa OECD við stefnumótun á Íslandi}

Eins og fram hefur komið eru íslenskir fulltrúar að nýta sér ýmsar afurðir OECD. Aftur á móti er fjöldi afurða sem Ísland hefur ekki nýtt sér á síðastliðnum árum af ýmsum ástæðum. Málefnið hefur kannski ekki verið á dagskrá, takmarkaður umbætur í farvatninu, afurðir falla illa að íslensku samfélagi, takmarkaður áhugi á samstarfi o.s.frv.

Sé litið yfir töflu 2 sem er afrakstur síðustu priggja PIR kannana hér á landi má greina nokkra málaflokka sem hafa verið í umræðunni síðastliðin ár og unnar hafa verið stefnur og áætlanir um. Detta eru málaflokkar eins og frumkvöðlastarf, neytendamál, innflytjendamál, umhverfismál, landbúnaðarmál og sjávarútvegsmál. Vissulega skiptir hér máli hverjir tóku pátt í könnuninni og pað kann að vera að sumar afurðir voru nýttar en pær upplýsingar ekki komið fram í könnuninni eða við yfirferð fastanefndarinnar. Pegar mynd 4 var hins vegar skoðuð mátti sjá að fulltrúar ráðuneyta og stofnana sem pessir málaflokkar heyra undir eru í færri kantinum sem kann að skýra minni notkun á pessum afurðum. 
Tafla 2. Málaflokkar par sem íslenskir fulltrúar voru međ enga eđa mjög litla svörun

\begin{tabular}{|c|c|c|c|}
\hline Afurđir & 2013-14 & 2015-16 & $2017-18$ \\
\hline 1.2.1 Atvinnurekstur, iðnađur og staðbundin próun & $x$ & $x$ & $x$ \\
\hline 1.2.4 Ferđabjónusta & $x$ & & \\
\hline 1.3.1 Stafrænt hagkerfi & $x$ & $x$ & $x$ \\
\hline 1.3.2 Vísindi og tækni & $x$ & $x$ & $x$ \\
\hline 1.3.5 Neytendastefna & $\mathrm{x}$ & $\mathrm{x}$ & $\mathrm{x}$ \\
\hline 2.1.4 Hæfni og símenntun & & & $\mathrm{x}$ \\
\hline 2.2.1 Vinnumarkađsmál & & $x$ & \\
\hline 2.2.2 Innflytjendastefnur & $\mathrm{x}$ & $x$ & $x$ \\
\hline 2.2.3 Velferđarmál & $x$ & $x$ & $\mathrm{x}$ \\
\hline 2.3.1 Jafningjaúttektir í umhverfismálum & & & $x$ \\
\hline 2.3.2 Loftslagsbreytingar og stjórnun náttúruauđlinda & $x$ & $x$ & $\mathrm{x}$ \\
\hline 2.3.3 Umhverfi, heilsa og öryggi & & $x$ & $\mathrm{x}$ \\
\hline 2.3.4 Umhverfistæki og nýsköpun & $x$ & & \\
\hline 2.3.5 Grænn vöxtur og sjálfbær próun & $\mathrm{x}$ & & \\
\hline 2.4.1 Árangur í heilbrigđispjónustu & & & $x$ \\
\hline 3.1.1 Viðskipta- og innanlandsstefnur & $\mathrm{x}$ & & \\
\hline 3.1.2 Verslun með pjónustu & $x$ & & \\
\hline 3.1.4 Útflutningur & $\mathrm{x}$ & & \\
\hline 3.2.1 Matvæla- og landbúnađarstefna & $x$ & & \\
\hline 3.2.2 Landbúnađarfæđi, viðskipti og próun & $\mathrm{x}$ & $x$ & $\mathrm{x}$ \\
\hline 3.2.3 Landbúanađur og sjálfbærni i sjávarútvegsmálum & $x$ & $x$ & \\
\hline 4.1.1 Fjárfestingar & $x$ & $x$ & \\
\hline 4.1.4 Gegn spillingu & & & $x$ \\
\hline 4.1.3 Stjórnarhættir & $x$ & & $x$ \\
\hline 4.1.5 próun í einkageiranum & $\mathrm{x}$ & $\mathrm{x}$ & \\
\hline 4.2.1 Samkeppni & $x$ & & \\
\hline 4.3.4 Staðbundnar próunarstefnur & $x$ & & \\
\hline 4.3.5 Lög og reglur & $x$ & $x$ & \\
\hline 5.1.1 Stefnur til að draga úr fátækt, sjálfbærni & $\mathrm{x}$ & $\mathrm{x}$ & $\mathrm{x}$ \\
\hline 5.1.2 próunarsamvinna & $\mathrm{x}$ & & \\
\hline 5.1.3. Tölfræði um ábyrgð og gagnsæja fjármögnun & $\mathrm{x}$ & $x$ & \\
\hline 5.1.4 Samstarf um alpjóđlega próunarsamvinna & $\mathrm{x}$ & & \\
\hline 5.1.5 Stuðningur við tölfræði & $x$ & $x$ & \\
\hline 5.1.6 Greining og stefnur í próunarmálum & $x$ & & \\
\hline 6.2.1 Tölfræđi & $\mathrm{x}$ & $\mathrm{x}$ & $\mathrm{x}$ \\
\hline
\end{tabular}


Раð fer ekki milli mála að peim fer fækkandi málaflokkunum sem íslensk stjórnsýsla veitir litla athygli eða nýtir sér mjög takmarkað. Á pessu tímabili fjölgar íslenskum sérfræðingum um helming sem sækja fundi hjá stofnuninni, fara úr rúmlega 100 árin 20132014 í rúmlega 200 árin 2017-2018 sem kann að skýra af hverju pað eru færri málaflokkar nú sem fá litla sem enga svörun í PIR könnunum OECD.

\section{Umræða og lokaorð}

Samband Efnahags- og framfarastofnunarinnar (OECD) og íslenskrar stjórnsýslu hefur styrktst á undanförnum tíu árum og má segja að pað hafi sennilega aldrei verið eins og náið í 60 ára sögu stofnunarinnar. Ótal dæmi styðja pessa fullyrðingu, bæði aukin fundasókn opinberra aðila á viðburðum skipulögðum af OECD, p.e. fundir nefnda/ vinnuhópa og ráðstefnur. Aukin nýting íslenskrar stjórnsýslu á afurðum stofnunarinnar, p.e.a.s. úttektum, tillögum og skýrslum í stefnumótandi tilgangi hér heima fyrir. Auk pess hefur framkvæmdastjóri OECD nokkrum sinnum komið til landsins á undanförnum árum í peim tilgangi að halda fyrirlestra eða til að kynna úttektir OECD. pær hafa jafnan verið kynntar á opinberum blaðamannafundum með ráðamönnum. Einnig hafa verið haldnar ráðstefnur hér á landi með pátttöku sérfræðinga frá OECD.

Í meginatriðum er greiningin að skoða fjóra pætti. Í fyrsta lagi, pátttöku íslenskrar stjórnsýslu í starfi OECD. Í öðru lagi, notkun íslenskrar stjórnsýslu á afurðum OECD. Í priðja lagi í hvaða tilgangi afurðir OECD eru nýttar innan íslenskrar stjórnsýslu. Í fjórða lagi, afurðir sem íslensk stjórnsýsla gæti verið að nýta sér en er ekki að gera. Раð fer ekki milli mála að íslensk stjórnsýsla er í mörgum tilvikum að nýta sér tillögur, tölfræði, viðmið og annað pessar háttar sem gefið er út af OECD. Dæmin í töflu 1 gefa jafnframt til kynna að pað skiptir máli að stuðst er við afurðir OECD og er jafnan vísað til stofnunarinnar í opinberum skjölum.

Álykta má sem svo að almenn ánægja sé með afurðir OECD hér á landi í ljósi pess að sífellt fleiri opinberir aðilar sækja fundi og aðra viðburði á vegum stofnunarinnar. Stofnunin, sem leidd hefur verið af sama framkvæmdastjóranum undanfarin 15 ár, hefur sett fram áherslur sem höfða til íslenskrar stjórnsýslu og skilar af sér afurðum sem stjórnsýslan telur rétt að nýta sér við stefnumótun og ákvörðunartöku. Pegar spurt er hvort afurðir OECD séu notaðar kemur fram að á Íslandi voru afurðir OECD notaðar i 67\% tilfella sem grundvöllur til umræðna um stefnumótun árin 2017-2018. Í 6\% tilfella voru pær notaðar sem grundvöllur stefnubreytinga á sama tímabili. Álíka tölur má finna fyrir tímabilin 2013-2014 og 2015-2016. Niðurstöður kannanna PIR gefa hins vegar ekki nægjanlega góðar upplýsingar um hvaða leiðir hafi helst verið notaðar við flutning.

Fjallað var um fjórar meginleiðir stefnuyfirfærslu að framan, afritun (e. copying), eftirlíking (e. emulate), samtenging (e. combinations) og innblástur (e. inspiration). Gera má ráð fyrir pví að ráðuneyti og stofnanir reyni að líkja eftir (e. emulate) eins og hægt er en í slíkum tilvikum eru hugmyndir að baki stefnum og áætlunum fluttar. Mun líklegra er að um slíkan flutning sé að ræða heldur en t.a.m. afritun (e. copying), sem felur í sér beinan og alhliða flutning. Samhengi hlutana skiptir máli og hafa parf pað í huga áður en ákveðið að er taka eitthvað upp sem reynst hefur vel í öðru landi. petta er áskorun sem 
OECD stendur jafnan frammi fyrir, p.e. að meta að hvaða leyti úrræði á einum stað getur einnig skilað árangri á öðrum stað.

Fram kemur í greiningunni að pað eru tiltekin ráðuneyti og stofnanir sem eiga náið samstarf við OECD. Pau ráðuneyti sem leita minna til OECD kunna að sækja samanburð, tölfræði og upplýsingar annað en til OECD. Sumir málaflokkar falla undir EES samstarfið og kann umfjöllun á vettvangi ESB að skipta meira máli fyrir pessa málaflokka en pað sem OECD hefur upp á að bjóða. Einnig ber að nefna Norðurlandasamstarfið, en í mörgum tilvikum er verið að leita fordæma á Norðurlöndum pegar kemur að stefnumótun. Könnun OECD leiðir íljós að íslensk stjórnsýsla leitar minna til OECD vegna málaflokka eins og umhverfismála, ýmissa velferðarmála og landbúnaðarmála. Mögulega er svarið að finna í ofangreindum skýringum en einnig kunna pólitískar áherslur ráðamanna að skipta máli og vel kann að vera að áherslur OECD á framangreindum sviðum séu ekki ráðamönnum að skapi og pví sé leitað annað.

Greiningin skoðar OECD út frá peirri forsendu að stofnunin sé lánveitandi stefna, hugmynda, áherslna og að Ísland sé piggjandi. pess ber bó að geta að Ísland hefur ekki einvörðungu verið piggjandi á pessari löngu vegferð. Íslenskir opinberir starfsmenn hafa verið virkir pátttakendur í starfi stofnunarinnar og lagt hugmyndir og nálganir að mörkum. Pær hafa síðar verið teknar upp með mjög markvissum hætti hjá stofnuninni, nægir að nefna nýlegt dæmi um kynjaða fjárlagagerð.

Eins og fram hefur komið hefur OECD hvorki „refisvönd“ né „gulrót“ og parf stofnunin pví að reiða sig á gæði afurða sinna og náið samstarf með aðildarríkjunum. Takist hvorugt er grundvöllur fyrir starfseminni brostinn. Stofnunin parf pví að vera sveigjanleg og í takti við tíðarandann hverju sinni til að skipta enn máli í alpjóðasamfélaginu. Að sama skapi hefur hún verið gagnrýnd fyrir að elta nýjustu tískufyrirbrigðin í stjórnkerfisfræðunum. Er petta hins vegar gert í peirri von um að vera á undan og hafa eitthvað fram að færa gagnvart aðildarríkjunum. Vegurinn sem OECD parf að ferðast er pví vandrataður. Engu að síður geta kreppur líkt og núverandi kórónuveirufaraldur veitt alpjóðastofnunum tækifæri til að gera sig gildandi eins og OECD hefur pegar gert með sínum viðburðum, útgáfum og vefsíðu.

Раð verður áhugavert að sjá hvernig tímabilið 2019-2020 kemur út úr könnunum OECD. Frá pví kórónuveirufaraldurinn hófst hefur fundasókn breyst. Stofnunin hefur bæði boðið upp á fleiri viðburði og styttri. Fundir nefnda og starfshópa eru með öðru sniði, standa yfir í fleiri daga og eru styttri til að mæta kröfum aðildarríkja utan Evrópu. Ekki er hægt að segja hvort pessi aðlögun hafi veikt eða styrkt tengsl Íslands við stofnunina. Pá koma fjarfundir seint í stað peirra tengsla sem myndast pegar fólk hittist í eigin persónu.

Með pessari grein hefur verið sýnt fram á að íslensk stjórnsýsla er að nýta sér afurðir OECD við stefnumótandi ákvörðunartöku hér á landi. Áhugavert væri að skoða nánar hverjir séu leiðandi í pessu ferli, eru pað t.a.m. embættismennirnir eða pólitískir ráðamenn? Jafnframt er tilefni til pess að greina eðli og umfang yfirfærsla á tilteknum stefnumálum með markvissari hætti en gert hefur verið í pessari grein. •ó að íslensk stjórnsýsla geti tekið virkari pátt í starfi OECD á fleiri sviðum má ekki vanmeta pann tíma sem fer 
í að taka pátt í alpjóðasamstarfi. Starfsemi OECD er pess eðlis að stofnunin er að fást við flest alla málaflokka fyrir utan varnarmálin. Đað eru pví mikil tækifæri fyrir íslenska stjórnsýslu að nýta sér pað sem OECD hefur upp á að bjóða. Áhugavert verður að fylgjast með nýjum framkvæmdastjóra stofnunarinnar, Mathias Cormann, sem tók við fyrr í sumar en áherslur hans kunna að hafa áhrif á pað hvernig samstarf OECD og Íslands mun próast á komandi árum.

\section{Tilvísanir}

1 https://www.oecd.org/sdd/prices-ppp/oecd-share-in-world-gdp-stable-at-around-50-per-cent-inppp-terms-in-2017.htm

2 http://www.fatf-gafi.org/media/fatf/documents/reports/mer4/MER-Iceland.pdf

3 https://www.stjornarradid.is/efst-a-baugi/frettir/stok-frett/2019/09/16/Ny-skyrsla-OECD-Lifskjor-a-Islandi-med-thvi-besta-sem-thekkist-/

4 https://www.althingi.is/altext/stjt/2013.142.html

5 https://www.althingi.is/altext/151/s/0757.html

6 https://www.stjornarradid.is/media/forsaetisraduneyti-media/media/frettir2/Vondud-loggjof--februar-2017.pdf

7 https://www.stjornarradid.is/media/forsaetisraduneyti-media/media/utgefidefni/sidareglurstjr-09.pdf

8 https://www.samkeppni.is/media/raedur-2020/RAEDA-Samkeppnismat-OECD.pdf

\section{Heimildaskrá}

Aubrey, H. (1967). Atlantic Economic Cooperation: The Case of the OECD. New York: Council on Foreign Relations/Praeger.

Benson, D. og Jordan, A. (2011). „,What have we Learned from Policy Transfer Research? Dolowitz and Marsh Revisited“, Political Studies Review 9(3), 366-378.

Camps, M. (1975). First World' Relationships: The Role of the OECD. New York/ Washington/London: Council on Foreign Relations / Praeger.

Carroll, P. (2013). ,Policy Transfer and Accession: A Comparison of Three International Governmental Organisations", Journal of Comparative Policy Analysis: Research and Practice 20(4), 345-353.

Carroll, P. og Kellow, A. (2011). The OECD: A Study of Organisational Adaptation. Cheltenham: Edward Elgar.

Coleman, W. (1994). „Policy convergence in banking: a comparative study“, Political Studies XLII, 274-292.

Dolowitz, D. and March, D. (1996). „Who learns what from whom: A review of the policy transfer literature", Political Studies 44, 343-357.

Dolowitz, D. og March, D. (2000). „Learning from abroad: The role of policy transfer in contemporary policymaking“, Governance 13(1), 5-23.

Dolowitz, D. og Marsh, D. (2012). „The future of policy transfer research“, Political Studies Review 10(3) 339-345.

Evans, M. og Davies, J. (1999). „Understanding Policy Transfer: A multi-level, multi-disciplinary perspective“, Public Administration 77(2), 361-385.

Forsætisráðuneytið (2010). Sambent stjórnsýsla. Reykjavík: Forsætisráðuneytið.

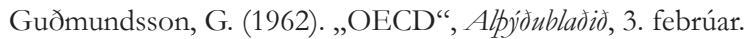

Guðmundsson, B. (1964). „Ísland og OECD“, Visiri, 1. júní.

Haas, P. (ritsti.). (1992). „Knowledge, power and international policy coordination“, sérstök útgáfa International Organisation 46(1). 
Clifton, J. og Díaz-Fuentes, D. (2014). „The OECD and "The Rest”: Analyzing the Limits of Policy Transfer", Journal of Comparative Policy Analysis: Research and Practice 16(3), 249-265. DOI: 10.1080/13876988.2013.877674.

Lendvai, N. og Stubbs, P. (2007). „Policies as translation: situating transnational social policies“, í Hodgson, S.M. og Irving, Z. (ritsti.), Policy Reconsidered: Meanings, Politics and Practices (bls. 173-190). Bristol: The Policy Press

Mahbubani, K. (2012). „The OECD: A classic sunset organization“, Global Policy 3(1), 117-118.

Majone, G. (1991). „Cross-National Sources of Regulatory Policymaking in Europe and the United States“, Journal of Public Policy 11:1, 79-106.

Mold, A. (2010). Maddison's forecasts revisited: What will the world look like in 2030? Sótt af http://www. voxeu.org/article/what-will-world-look-2030-maddison-s-forecasts-revisited

OECD (2007). Council Resolution on Enlargement and Enhanced Engagement. Sótt af https://www.oecd.org/ brazil/oecdcouncilresolutiononenlargementandenhancedengagement.htm

OECD (2010). Global Perspectives on Development: Shifting Wealth. Paris: OECD.

Quah, D. (2011). ,The Global Economy's Shifting Centre of Gravity“, Global Policy 2(1), 3-9.

Pal, L. (2012). Frontiers of Governance: The OECD and Global Public Management Reform. London: Palgrave Macmillan

Pal, L. (2014). „Introduction: The OECD and Policy Transfer: Comparative Case Studies“, Journal of Comparative Policy Analysis: Research and Practice 16(3), 195-200. DOI: 10.1080/13876988.2014.910910.

Parsons, W. (1996). Public Policy. Cheltenham, England: Edward Elgar.

Robertson, D. (1991). „Political Conflict and Lesson Drawing“, Journal of Public Policy 11(1), 55-78.

Robertson, D. og Waltman, H. (1992, september). The Politics of Policy Borrowing. Erindi flutt á árlegum fundi the American Political Science Association, Chicago, BNA.

Rose, R. (1991). „What Is Lesson-Drawing?“", Journal of Public Policy 11(1), 3-30.

Rose, R. (1993). Lesson-Drawing in Public Policy: A Guide to Learning Across Time and Space. Chatham, N.J: Chatham House Publishers.

Stone, D. (2017). „The Transfer of Policy Failure: Bricolage, Experimentalism and Translation“, Policy and Politics 45(1), 55-70.

Vísir (1960). „Ný stofnun í stað OEEC“, 15. desember. 